IZA DP No. 5282

Early Childhood Stimulation Interventions in Developing Countries:

A Comprehensive Literature Review

Helen Baker-Henningham

Florencia Lopez Boo

October 2010 


\title{
Early Childhood Stimulation Interventions in Developing Countries: A Comprehensive Literature Review
}

\author{
Helen Baker-Henningham \\ University of the West Indies, Mona \\ Florencia Lopez Boo \\ Inter-American Development Bank \\ and IZA
}

\section{Discussion Paper No. 5282 \\ October 2010}

\author{
IZA \\ P.O. Box 7240 \\ 53072 Bonn \\ Germany \\ Phone: +49-228-3894-0 \\ Fax: +49-228-3894-180 \\ E-mail: iza@iza.org
}

Any opinions expressed here are those of the author(s) and not those of IZA. Research published in this series may include views on policy, but the institute itself takes no institutional policy positions.

The Institute for the Study of Labor (IZA) in Bonn is a local and virtual international research center and a place of communication between science, politics and business. IZA is an independent nonprofit organization supported by Deutsche Post Foundation. The center is associated with the University of Bonn and offers a stimulating research environment through its international network, workshops and conferences, data service, project support, research visits and doctoral program. IZA engages in (i) original and internationally competitive research in all fields of labor economics, (ii) development of policy concepts, and (iii) dissemination of research results and concepts to the interested public.

IZA Discussion Papers often represent preliminary work and are circulated to encourage discussion. Citation of such a paper should account for its provisional character. A revised version may be available directly from the author. 


\section{ABSTRACT \\ Early Childhood Stimulation Interventions in Developing Countries: A Comprehensive Literature Review ${ }^{*}$}

This report reviews the effectiveness of early childhood stimulation interventions in developing countries. The report aims to answer the questions: What works in terms of early stimulation for young children in developing countries? For whom and under what conditions do these programs work and why do they work. The report is divided into several sections. Firstly, a brief discussion of the importance of early stimulation for young children in developing countries is provided. Secondly, the methods used to identify and characterize studies are provided and a review of randomized or quasi-experimental trials is presented. Thirdly, a review of the evidence for who benefits most from early interventions is presented followed by a review of program characteristics that affect the success of interventions and an examination of potential mechanisms through which interventions achieve their effects. Finally, recommendations for practice and future research are provided.

JEL Classification: J13, J18, J24

Keywords: child development, early stimulation, mothers, parenting, developing countries

Corresponding author:

Florencia Lopez Boo

Social Protection and Health Division

Inter-American Development Bank

1300 New York Ave.

Washington, DC 20577

USA

E-mail: florencial@iadb.org

\footnotetext{
* The information and opinions presented in this paper are entirely those of the author(s), and no endorsement by the Inter-American Development Bank, its Board of Executive Directors, or the countries they represent is expressed or implied. The authors thank the comments from an anonymous peer-reviewer, Norbert Schady and Ferdinando Regalia.
} 


\section{Introduction: importance of early stimulation interventions for children in developing countries}

In this section, four main issues are introduced which provide a rationale for investing in early childhood stimulation interventions in developing countries. These issues include: 1) the extent and nature of the problem, 2) the nature of child development including the importance of the early years, 3) the technology of skill formation and 4) the centrality of the family environment for optimal child development.

Large numbers of children in developing countries are exposed to multiple risk factors in the early years of life including poor health, malnutrition and low levels of home stimulation. Risk factors covary - (for example, poverty covaries with low maternal education, teenage parenting, child undernutrition, low birth weight, high levels of maternal depression, unsafe neighborhoods and low levels of stimulation in the home) - and children exposed to multiple risk factors are at heightened risk for poor development. For example, the number of risk factors experienced by children by age 3 years in a Guatemalan study was associated with a linear decrease in cognition and school achievement in adolescence (Gorman \& Pollitt 1996). Grantham-McGregor and colleagues (2007) estimate that over 200 million children under five years of age in developing countries are not reaching their developmental potential due to poverty and poor health and nutrition. These children are likely to do poorly at school and to have limited economic opportunities in adulthood. This in turn perpetuates the cycle of poverty and contributes to the intergenerational transmission of poverty, poor health and development. This loss of children's developmental potential was estimated to lead to a $20 \%$ deficit in adult income (Grantham-McGregor et al. 2007). Thus in addition to perpetuating social inequities, poor development has serious implications for national development.

Child development is multi-dimensional and includes cognitive-language, sensory-motor, and social-emotional domains, all of which are interdependent. Although much early literature focused on the importance of early child cognition for later development, there is increasing recognition of the importance of non-cognitive domains in predicting children's academic attainment, productivity and social functioning in adulthood.

Child development is also multi-determined being influenced by an interaction between children's genetic inheritance, biological state (e.g. health and nutritional status) and the 
proximal (e.g. quality of maternal-child interaction) and distal (e.g. neighborhood characteristics) environment (Wachs 2000). During the first few years of life, rapid growth and development occur in all domains forming a strong foundation for learning later skills (National Research Council Institute of Medicine 2000). Children living in disadvantaged environments are more likely to be exposed to biological and environmental risks which affect brain growth and can lead to lasting changes in the developing brain's structure and function. By the ages of four to six years, persistent gaps have emerged in children's development in both cognitive and noncognitive domains between children from disadvantaged backgrounds and their more advantaged peers (Heckman 2006).

There is a substantial evidence base showing that exposure to disadvantaged environments during the first few years of life is associated with many negative outcomes in adolescence and adulthood including lower IQ and academic attainment, increases in antisocial behaviour and lower earnings in adulthood (Heckman \& Masterov 2007). In addition, cumulative exposure to risk in early childhood is associated with poor health and chronic disease in adulthood indicating that health disparities also have their origins in early childhood (Shonkoff et al. 2009).

Probably most importantly for the purposes of developing countries' progress; a large body of research documents that the social and economic success of investments in human capital in later childhood and adolescence will be influenced by the cognitive and non-cognitive skills (e.g. social and emotional skills) that children bring to the task (Hernstein \& Murray 2004, Murnane et al. 1995, Heckman et al. 2006). Children with higher levels of the prerequisite skills will benefit more whilst disadvantaged children will benefit less. Furthermore, disadvantaged children are less likely to take advantage of later learning opportunities than their more advantaged peers as demonstrated for example, by greater school drop out amongst disadvantaged children in developing countries (Grantham-McGregor et al. 2007). Studies of skill formation have shown that interventions in the early childhood years are one of the rare examples of interventions that are both equitable and efficient - that is, the interventions reduce inequalities whilst also raising the productivity of the society as a whole (Heckman 2006; Cunha et al. 2010). Interventions starting later in life require remediation of developmental deficits caused by early disadvantage and are more costly and less effective. Early interventions thus increase the efficiency of later interventions and the best results are evident when effective early 
interventions followed by high quality interventions at later ages (Heckman 2006). Cunha and colleagues (2005) describe this phenomenon as the 'self-productivity' and 'complementarity' of the learning process leading to a 'skill multiplier' effect. 'Self-productivity' refers to the concept that skills learned at one stage of the learning process enhance learning at later stages. 'Complementarity' means that early investments are most effective when followed by later investments. These two concepts lead to the notion that "skill begets skill; learning begets learning" (Cunha et al. 2005, pp.80). Early investments have been shown to be particularly important in terms of cognitive skills with investments at early ages yielding much larger returns than investments at later ages as there is limited substitutability across time periods (Cunha et al. 2010). For non-cognitive skills there is larger scope to make up early deficits because early and late investments are more closely substitutable (Cunha et al. 2010). This will have implications in the design of policy interventions

But what are the main determinants of child development? The negative effects of disadvantaged environments in the early childhood years point to the importance of the family and the home environment for promoting optimal child development. Since the publication of the well-known Coleman Report (1966), it has been recognized that inequalities in student attainments are primarily a result of inequities in family environments rather than school environments (Heckman 2006). Furthermore, there is substantial evidence from developed countries that early interventions that support caregivers and provide developmentally appropriate learning opportunities for young children lead to significant benefits across multiple outcomes in later life, including higher cognition and school achievement, reduced placement in special education classes, less grade retention, less crime and delinquency, lower rates of teenage pregnancy and increased earnings and less dependence on welfare in adulthood (Heckman \& Masterov 2007, Yoshikawa 1995). Walker and colleagues (2007) identify inadequate cognitive stimulation as one of the four most urgent modifiable risk factors that are encountered by young children in developing countries (the other three urgent risk factors identified were stunting, iodine deficiency and iron deficient anemia) while Engle and colleagues (2007) provide evidence that early child development programs in developing countries are successful in promoting young children's development, thus preventing the loss of children's developmental potential. They suggest that the most effective programs are those that 'provide direct learning experiences to children and families, are targeted towards younger and disadvantaged children, are of longer 
duration, high quality and high intensity, and are integrated with family support, health, nutrition or educational systems and services.' (Engle et al. 2007, pp. 229).

There are two recent reviews of early childhood interventions globally. Nores \& Barnett (2010) reviewed the evidence of the effects of early childhood interventions conducted outside the US on child cognition, behavior, schooling and health. Thirty interventions were identified and the average effect size on child outcomes was 0.26 to 0.39 . Educational interventions and mixed nutrition and educational interventions produced the greatest benefits to children's cognition (effect size 0.35) in comparison with cash transfer programs (effect size 0.17) or nutrition alone (0.25). Educational interventions also had the largest effect size on schooling and behavioral outcomes although nutrition interventions had the largest impact on child health. Interventions were effective both in the short and over the long term except for the health domain in which the effect sizes decreased over time (Figure 1).

Figure 1. Overall effect sizes of early childhood interventions on child cognition, behavior, schooling and health outcomes over the short and longer term

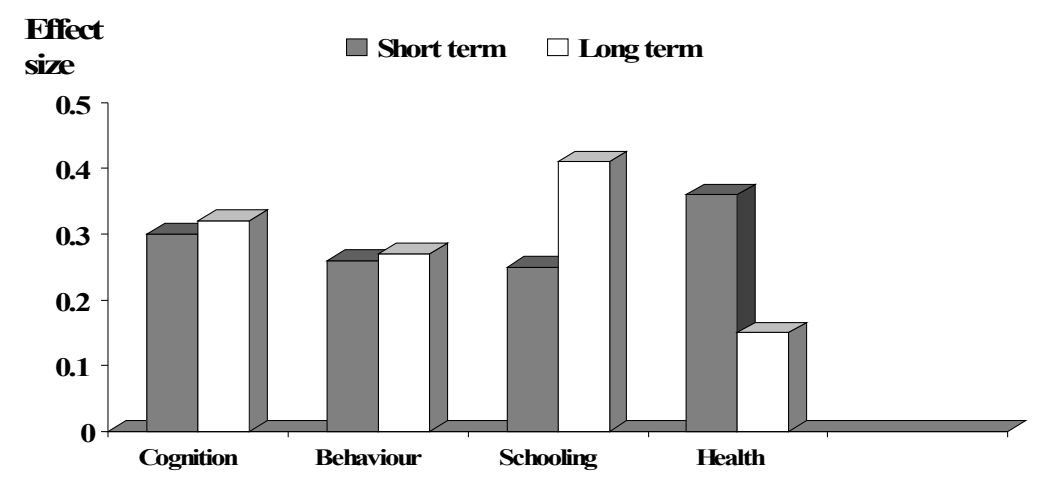

Source: Nores \& Barnett 2010

Maulik \& Darmstadt (2009) conducted a descriptive review of the evidence for the effectiveness of interventions targeting children in the birth to age three age range that used low cost stimulation interventions including play, reading, music and tactile stimulation (e.g. kangaroo care for preterm babies). From their review they concluded that play-based interventions and interventions that promoted shared reading were the most effective and feasible interventions for developing countries. 
In this paper we extend and complement Nores \& Barnett (2010) and Maulik and Darmstadt (2009) in the following ways. Firstly, this paper is a more comprehensive review of studies from low and middle income (LAMI) countries. We describe in detail 28 interventions from LAMI countries - only ten of these interventions are included the review by Nores \& Barnett and ten are described in the paper by Maulik and Darmstadt. Secondly, this review is focused only on interventions that aim to promote children's development through stimulation, primarily through parenting interventions. Interventions largely aimed at promoting child health (e.g. kangaroo care), nutrition only interventions and cash transfer programs have been excluded from this review, as opposed to the earlier reviews. This allows for a more in-depth examination of issues that are important in early stimulation interventions. Thirdly, given the importance of the home environment and maternal well-being for young children's development, we have extended the scope of this review to include the benefits of intervention to caregivers. Finally, in addition to investigating the effect of early childhood interventions on child and maternal outcomes we examine issues relating to implementation (e.g. what characterizes an effective program, differential effectiveness of interventions, and the mechanism through which these interventions work). These are important issues to be considered when scaling-up effective interventions.

\section{Methods}

A review of early stimulation interventions for children aged birth to five years, with a particular focus on the birth to three year age group was undertaken to facilitate an in-depth examination of pertinent aspects of the programmes.

Studies were included if:

- The study was conducted in a low or middle income country

- A reasonable comparison strategy was employed (e.g. randomized trial or quasiexperimental evaluation)

- There was an explicit focus on improving child development and/or maternal outcomes. 
- The study described a stimulation intervention that occurred between pregnancy and age 3 years and/or that described a stimulation intervention in children aged 4-5 that would be appropriate for children age 3 and under.

Studies were excluded if:

- They dealt with preschool provision only in the age 3-5 age range

- They involved children in institutions or were specifically designed to be appropriate for a specialized group of children e.g. kangaroo care for premature infants and community rehabilitation for disabled children.

The following databases were searched: Medline, Psychinfo, EMBASE, Google Scholar and in addition hand searches of key articles and reviews were conducted and experts in the field were contacted to identify further studies. The main focus of this report was on reviewing studies that had been published in peer review journals which primarily consisted of efficacy studies. However, reports of large scale program evaluations were also reviewed and information on these were included if they provided additional information and insights not provided through the efficacy studies.

The studies were reviewed for the effects of early stimulation interventions on child and maternal outcomes both concurrently and over the long term.

Child outcomes were categorized as:

1. Child mental and motor development and/or IQ: measured by standardized scales

2. Child behaviour: includes observed behaviour, ratings by teachers and parents, self report and official records

3. Schooling: including school achievement, retention in grade, placement in special education and high school graduation

\section{Nutritional status}

5. Health

Maternal outcomes were categorized as:

1. Parenting: which includes observed parent child interaction, parenting attitudes, parenting knowledge, and stimulation provided in the home.

2. Psychosocial function: including depression, anxiety, self-esteem as well as stresses and buffers such as social support and chronic stressors. 
3. Maternal life course: education, employment, child bearing, criminality, drug and alcohol abuse or women's status in the home

An additional category of mother-child interaction was included to categorise outcomes that measured the synchrony between mother and child or that examined mother and child initiated interactions.

Details of the sample, duration of the program, setting (home visiting or centre based), content of the intervention, personnel delivering the intervention, training provided to intervention staff and short and long term outcomes are given in tables 1 to 5 . The countries in which the evaluations were conducted were also classified using the World Bank classification of economies.

\section{Review of Studies}

A total of forty five journal articles describing twenty six studies of early stimulation interventions for young children from eleven developing countries were identified. The studies were divided into five categories according to the group of children targeted and/or the primary focus of the intervention. These five categories are:

1. Stimulation intervention in early infancy with a primary focus on promoting maternalchild interaction

2. Stimulation interventions with disadvantaged children and their families

3. Stimulation only interventions with undernourished children and their families and

4. Combined stimulation and nutrition programs.

5. Stimulation interventions with children at-risk due to health problems. 


\section{Stimulation Interventions in Early Infancy with a Primary Focus on Promoting Maternal Child Interaction}

Four stimulation interventions were identified in this category and all four were conducted in upper-middle income countries. The studies are described in detail in Tables 1. Three of the studies were randomized controlled trials and one used a well matched control group. All four interventions involved promoting mothers' sensitive and responsive interactions with her infant. The duration of the interventions varied from one fifty minute session to 6 months of intervention and three of the interventions involved home visiting by paraprofessionals (Cooper et al. 2002, 2009; Gardner et al. 2003). In these three interventions, the paraprofessionals received initial training in the intervention, ongoing supervision was provided and a manual was available to ensure the stimulation intervention was delivered with fidelity.

\section{Child Outcomes}

Only one study measured infants' mental development and behaviour - an eight week intervention starting at birth led to significant benefits on a problem-solving test and to infants' cooperation and positive affect during the test session at age seven months (Gardner et al. 2003). One study, involving sixteen home visits finishing when the infants were five months old led to significant benefits to infant attachment status at 18 months (Cooper et al. 2009). Only one intervention reported the effect of intervention on growth and no benefits were found (Cooper et al. 2002). No studies included measures of benefits to children's schooling or academic achievement as the follow up period did not extend into the school-age period. Also, no child health outcomes were measured.

\section{Maternal Outcomes}

Two studies investigated the effect of intervention on parenting behavior and both of these studies were from South Africa and involved home visiting for the first 5-6 months of the infants' lives (Cooper et al. 2002, 2009) Significant benefits were reported in both studies and mothers participating in the intervention were found to be more sensitive, less intrusive and to show more positive affect to their children at 6 months (Cooper et al. 2002, 2009) and at 12 months (Cooper et al. 2009) and to be more responsive to their infants cries at 1 month (Wendland-Carro et al. 1999) compared to mothers in the control group. The two South African 
studies also measured mother's depressive symptoms and in one no significant benefits were found at 6 months (Cooper et al. 2002) while in the second study, intervention mothers reported significantly fewer depressive symptoms at 6 months but not at 12 months (Cooper et al. 2009). No studies included measures of maternal life course.

\section{Maternal-Child Interaction}

One study, from Brazil, which involved one training session with the mother before discharge from hospital (Wendland-Carro et al. 1999), measured the amount of synchronous behaviours between mother and child one month later and significant benefits were found for mother-infant dyads in the intervention group.

\section{Summary of Interventions in Early Infancy}

There are too few studies to draw any strong conclusions about the effectiveness of stimulation interventions in early infancy. However, the evidence suggests that interventions that promote mothers' sensitivity and responsiveness to her infant early in life can have significant benefits on mother's parenting behaviours and it was encouraging that in one study benefits were also found to infant attachment one year after the end of the intervention. There is insufficient evidence to determine if these interventions benefit children's mental or motor development and the evidence of benefits to mothers' mental health is inconsistent. 
Table 1: Stimulation Interventions in Early Infancy with a Primary Focus on Promoting Maternal-Child Interaction in Developing Countries

\begin{tabular}{|c|c|c|c|}
\hline Study & Sample & Intervention & Short term effects \\
\hline $\begin{array}{l}\text { South } \\
\text { Africa } \\
\text { Cooper et } \\
\text { al. } 2002 \\
\text { Upper- } \\
\text { middle } \\
\text { income } \\
\text { country }\end{array}$ & $\begin{array}{l}\text { Mothers recruited in } \\
\text { late pregnancy in a } \\
\text { periurban } \\
\text { settlement outside } \\
\text { Capetown with high } \\
\text { unemployment and } \\
\text { illiteracy. } \\
\text { Intervention group : } \\
\mathrm{n}=32 \\
\text { Control group } \\
\text { (n=32): mother- } \\
\text { infant dyads } \\
\text { matched on at least } \\
\text { two of: maternal } \\
\text { age, parity and } \\
\text { marital status in an } \\
\text { adjacent area }\end{array}$ & $\begin{array}{l}\text { Duration: } 6 \text { months } \\
\text { Conducted by: Paraprofessionals } \\
\text { Adaptation of the 'Health Visitor Preventive } \\
\text { Intervention Programme' incorporating key } \\
\text { principles of the World Health Organisation } \\
\text { document: 'Improving the Psychosocial } \\
\text { Development of Children'. } \\
\text { The intervention was delivered through home } \\
\text { visiting and provided support for the mother, } \\
\text { encouraged her in sensitive, responsive } \\
\text { interactions with her infant, sensitised the mother } \\
\text { to her infant's abilities using the Neonatal } \\
\text { Behavioural Assessment Schedule and provided } \\
\text { advice on management of sleep, crying and } \\
\text { feeding. } \\
\text { Intervention involved two antenatal visits, twice } \\
\text { weekly visits for } 4 \text { weeks postanatally, weekly for } \\
\text { the next } 8 \text { weeks, fortnightly for a month and then } \\
\text { monthly for } 2 \text { months - a total of } 20 \text { visits. } \\
\text { Training } \\
\text { Paraprofessionals received initial training over a } 4 \\
\text { month period and were provided with session by } \\
\text { session group supervision by an experience } \\
\text { community clinical psychologist. }\end{array}$ & $\begin{array}{l}\text { At } 6 \text { months post partum } \\
\text { Child Outcomes } \\
\text { Child Growth: } \\
\text { Significant effect of intervention on child weight and } \\
\text { height. } \\
\text { Maternal outcomes } \\
\text { Parenting (mother-infant interaction): } \\
\text { Intervention mothers were more sensitive in play and } \\
\text { tended to show more positive affect during feeding. } \\
\text { Pscychosocial function: } \\
\text { No significant effect of intervention on maternal } \\
\text { mood. }\end{array}$ \\
\hline
\end{tabular}


Table 1 (continued): Stimulation Interventions in Early Infancy with a Primary Focus on Promoting Maternal-Child Interaction in Developing Countries

\begin{tabular}{|c|c|c|c|}
\hline Study & Sample & Intervention & Short term effects \\
\hline $\begin{array}{l}\text { South } \\
\text { Africa } \\
\text { Cooper et } \\
\text { al. } 2009 \\
\text { Upper- } \\
\text { middle } \\
\text { income } \\
\text { country }\end{array}$ & 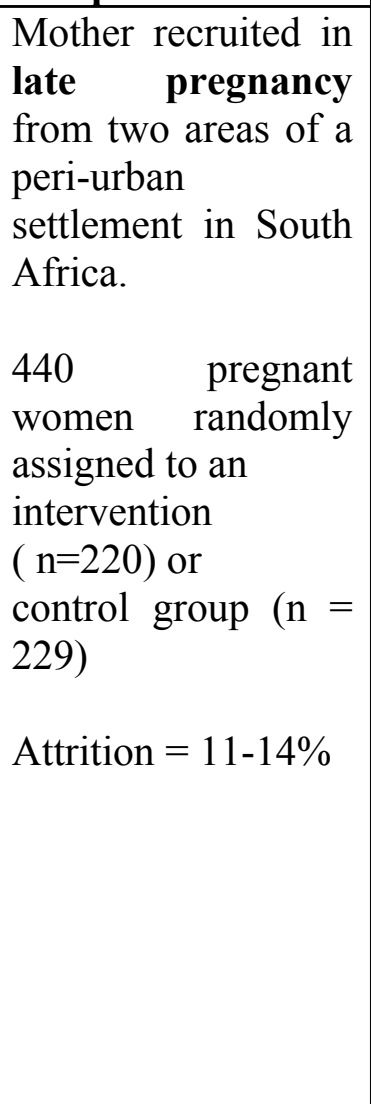 & $\begin{array}{l}\text { Duration: } 5 \text { months } \\
\text { Conducted by: Paraprofessionals } \\
\text { Intervention was similar to the Cooper et al. } 2002 \\
\text { study described above. } \\
\text { Mothers were visited at home for } 1 \text { hour twice } \\
\text { antenatally, weekly for the first eight postnatal } \\
\text { weeks, fortnightly for the next two months and } \\
\text { monthly for two months - a total of } 16 \text { visits } \\
\text { finishing at infant age } 5 \text { months. } \\
\text { Training } \\
\text { See study above by Cooper et al. } 2002\end{array}$ & $\begin{array}{l}\text { Child outcomes } \\
\text { Infant attachment: } \\
\text { Significantly more infants in the intervention group } \\
\text { were securely attached at } 18 \text { months than in the } \\
\text { control group. } \\
\text { (No association was found between mother-infant } \\
\text { relationship outcomes and infant attachment). } \\
\text { Maternal outcomes } \\
\text { Parenting: } \\
\text { At } 6 \text { and } 12 \text { months, intervention mothers were more } \\
\text { sensitive and less intrusive with their infants (effect } \\
\text { sizes = approx } 0.25 \text { ) } \\
\text { Maternal Psychosocial function: } \\
\text { Lower prevalence of depression in intervention } \\
\text { versus control group at } 6 \text { months ( } 21 \% \text { vs } 29 \% \\
\text { respectively) and } 12 \text { months (18\% vs } 28 \% \text { ) but not } \\
\text { statistically significant. } \\
\text { Less depressive symptoms among intervention } \\
\text { mothers at } 6 \text { and } 12 \text { months but differences only } \\
\text { significant at } 6 \text { months. } \\
\text { (Depression was not correlated with infant } \\
\text { attachment or mother-infant relationship variables.) }\end{array}$ \\
\hline
\end{tabular}


Table 1 (continued): Stimulation Interventions in Early Infancy with a Primary Focus on Promoting Maternal-Child Interaction in Developing Countries

\begin{tabular}{|c|c|c|c|}
\hline Study & Sample & Intervention & Short term effects \\
\hline $\begin{array}{l}\text { Porto } \\
\text { Alegre, } \\
\text { Brazil } \\
\text { Wendlan } \\
\text { d-Carro } \\
\text { et al. } \\
1999 \\
\text { Upper- } \\
\text { middle } \\
\text { income } \\
\text { country }\end{array}$ & $\begin{array}{l}38 \text { primiparous } \\
\text { mothers and their } \\
\text { full-term newborn } \\
\text { infants (with no } \\
\text { health } \\
\text { complications) } \\
\text { randomly assigned } \\
\text { to: } \\
\text { Intervention: } \mathrm{n}=19 \\
\text { or } \\
\text { Placebo: } \mathrm{n}=19 \\
17 \text { intervention and } \\
19 \text { control } \\
\text { completed } \\
\text { assessments }\end{array}$ & $\begin{array}{l}\text { Duration: } 1 \text { session } \\
\text { Conducted by: Professional (investigator) } \\
\text { Intervention involved one } 50 \text { minute session prior to } \\
\text { hospital discharge. During the session mothers } \\
\text { watched and discussed a videotape showing } \\
\text { information about newborn's competence to interact, } \\
\text { how to handle the infant affectionately and how to } \\
\text { interact with the infant. } \\
\text { The placebo condition involved a } 50 \text { minute session } \\
\text { conducted in a similar manner to the intervention } \\
\text { condition but focusing on basic caregiving skills (e.g. } \\
\text { hygiene) and infant health issues. } \\
\text { Training } \\
\text { Not specified }\end{array}$ & $\begin{array}{l}\text { Effects after } 1 \text { month: } \\
\text { Mother-child interaction } \\
\text { Intervention resulted in greater } \\
\text { frequency of synchronous behaviours } \\
\text { between mother and infant especially } \\
\text { vocal exchanges, looking at partner } \\
\text { and physical contact. } \\
\text { Intervention mothers were also more } \\
\text { responsive to infant crying and to } \\
\text { involuntary responses (e.g. sneezes, } \\
\text { coughs, hiccups). }\end{array}$ \\
\hline $\begin{array}{l}\text { Kingston, } \\
\text { Jamaica } \\
\text { Gardner } \\
\text { et al. } \\
2003 \\
\text { Upper- } \\
\text { middle } \\
\text { income } \\
\text { country }\end{array}$ & $\begin{array}{l}140 \text { term low birth } \\
\text { weight (LBW) } \\
\text { infants randomly } \\
\text { assigned to } \\
\text { intervention }(\mathrm{E} \mathrm{n}= \\
70) \text { or control }(\mathrm{C} \mathrm{n} \\
=70) \text {. }\end{array}$ & $\begin{array}{l}\text { Duration: } 8 \text { weeks } \\
\text { Conducted by: paraprofessionals (community health } \\
\text { aides) } \\
\text { Intervention involved weekly home visits by } \\
\text { community health aides of } 1 \text { hour duration from birth } \\
\text { to } 8 \text { weeks } \\
\text { Training } \\
\text { Health aides were given } 1 \text { week of training prior to } \\
\text { conducting the intervention and were closely } \\
\text { supervised throughout the intervention period. }\end{array}$ & $\begin{array}{l}\text { Child outcomes at } 7 \text { months: } \\
\text { Mental development: } \\
\text { Intervention benefited problem solving } \\
\text { on 'cover' means-end cognitive test } \\
\text { but no significant benefits were found } \\
\text { for a 2nd problem-solving test - } \\
\text { 'support' means-end test. } \\
\text { Behavior: } \\
\text { Intervention significantly benefited } \\
\text { infants' cooperation and positive affect } \\
\text { during the test session. }\end{array}$ \\
\hline
\end{tabular}




\section{Stimulation Interventions with Disadvantaged Children and Their Families}

Twelve stimulation interventions with disadvantaged children and their families in developing countries were identified and two of these included children aged 4-5 years. The studies are described in Table 2. Six studies came from upper middle income countries, three from lowermiddle income countries and three from low income countries. Only two of the studies used random assignment to the intervention or control condition (Jin et al. 2007, Rahman et al. 2008) while the remaining ten used a quasi-experimental design. The interventions varied in the age of the children on enrolment, duration of the intervention and the intensity of the intervention. The majority of the stimulation interventions involved a home-visiting component although in several studies, the home visiting was also complemented by a series of group meetings with the mothers (Rahman et al. 2008, Eickman et al. 2003, Klein \& Rye, 2004). One study used groups alone (Aboud 2007), one involved counseling sessions during a hospital visit (Ertem et al. 2006) and two involved centre based services for children although both these studies were primarily targeting children over age 3 years and also included a parent training component (Watanabe et al. 2005, Kagitcibasi et al. 2001, 2009). In six of the twelve studies, the intervention was delivered by trained paraprofessionals, one study used occupational therapists to run group parent workshops and paraprofessionals for the home visiting component (Eickmann et al. 2003), in two studies professionals delivered the intervention (Ertem et al. 2006, Magwaza \& Edwards 1991) and in three studies the qualifications of the intervention personnel were not provided (Watanabe et al. 2005, Jin et al. 2007, Sharma \& Nagar 2009). The interventions also differed in terms of the length of the intervention with one study reporting an intervention over a two week period (Ertem et al. 2006) and three studies reporting an intervention lasting two years (Powell \& McGregor 1989, Watanabe et al. 2005, Kagitcibasi et al. 2001). The content of the interventions shared many common characteristics and usually involved showing the mother age appropriate activities to do with her child using low cost materials and/or items in the home, providing suggestions and activities to facilitate mother-child interaction and/or providing information on nutrition, health care and child development. 


\section{Child Outcomes}

\section{Child Mental and Motor Development}

Ten studies measured children's mental development and nine found benefits. The only study that showed no benefits was a parenting programme in Bangladesh which involved weekly education sessions to groups of mothers (Aboud 2007). This study involved primarily group discussion and information sharing and the author suggested that the theoretical rather than practical nature of the intervention (that is, the limited amount of hands-on, practical activities and/or role plays) may be one reason for the lack of benefits to child development. Only three studies measured children's motor development (Sharma \& Nagar 2009, Eickmann et al. 2003, Jin et al. 2007) and all found benefits.

\section{Child Behavior}

Only three studies investigated the effect of intervention on child behaviour and all found benefits (Magwasa \& Edwards, 1991; Klein \& Rye 2004; Kagitcibasi et al. 2009). In South Africa a 10-week intervention led to significant benefits to children's task oriented behaviour, positive social behaviour and distractible behaviour (Magwasa \& Edwards 1991). In Turkey, mothers who had participated in a 2 year intervention involving fortnightly group meetings and fortnightly home visits reported that their children were less aggressive (Kagitcibasi et al. 2001) while in Ethiopia, a 3 month intervention focusing on maternal child interaction led to significant benefits to mother reports of child behaviour 6 years after the end of the intervention. Children in the intervention group were less hostile and aggressive, less anxious, less hyperactive and less distractible using a standardized scale (Klein \& Rye, 2004).

\section{$\underline{\text { Nutritional Status }}$}

Only two studies included children's nutritional status as an outcome and neither reported benefits of intervention on growth. Surprisingly, one study reported that children in the intervention group had lower weight for height than children in the control group (Aboud 2007). In this study, no pretest was conducted and hence it is possible that this difference reflected children's prior nutritional status.

\section{Child Schooling}

Only one study included measures of school achievement and benefits were found from both educational training and mother training for two years (from age three to five years) to children's 
school grades but not to scores on academic achievement tests over the short term and to school achievement at a 6-year follow up (Kagitcibasi et al. 2001). There was also a trend for children whose mothers had received training to be more likely to be enrolled in college at the 22 year follow-up (Kagitcibasi et al. 2009).

\section{Child Health}

No studies included measures of child health.

\section{Maternal Outcomes}

\section{Parenting}

Six studies evaluated the effect of stimulation on one or more aspects of parenting and all found benefits. Four studies reported benefits to mothers' knowledge of child development (Rahman et al. 2008, Powell et al. 2004, Aboud 2007, Jin et al. 2007), two reported benefits to mothers' selfreported practices (Powell et al. 2004, Kagitcibasi et al. 2001) and two reported benefits to the level of stimulation in the home (Aboud 2007, Ertem et al. 2006)

\section{Psychosocial Function}

Two studies reported the effect of stimulation on maternal psychosocial function and in neither study were any benefits found. In Jamaica, there were no significant differences in maternal selfesteem between mothers who had participating in a home visiting program for one year and a control group (Powell 2004) and in Pakistan, there was no benefit to mothers' mental distress from a home visiting programme for 6 months (Rahman et al. 2008).

\section{Maternal Life Course}

Only one study included outcome measures of benefits to maternal life course. In Turkey, mothers who had participated in an early stimulation programme involving biweekly group meetings and biweekly home visits reported significantly higher status within the home and better family relations six years after the end of the intervention (Kagitcibasi et al. 2001).

\section{Mother-Child Interaction}

One study investigated the effect of intervention on mother-child interaction and significant benefits to structured observations of mother child interaction (Klein \& Rye 2004). 


\section{Summary of Stimulation Interventions with Disadvantaged Children and Their Families}

The studies provide strong evidence that early stimulation interventions can benefit children's mental development and mothers' parenting practices over the short term. There is some evidence that stimulation in early childhood can also have significant benefits to child behaviour although only three studies examined this. There is no evidence from these studies that early stimulation can benefit children's nutritional status or maternal psychosocial function although few studies examined this. Similarly it is not possible to draw any conclusions about the benefits of early stimulation to children's schooling trajectories or maternal life course as only one study examined these outcomes. Only two studies included a long term follow-up and hence the evidence for sustained benefits from early stimulation is limited. However, both studies reported that some benefits of early stimulation were maintained, one after 6 years (Klein \& Rye 2004) and one after 22 years (Kagitcibasi et al. 2009). 
Table 2: Stimulation Interventions with Disadvantaged Children and Their Families in Developing Countries

\begin{tabular}{|c|c|c|c|}
\hline Study & Sample & Intervention & Short term effects \\
\hline $\begin{array}{l}\text { Rural } \\
\text { Pakistan } \\
\text { Rahman } \\
\text { et al. } \\
2008 \\
\text { Lower- } \\
\text { middle } \\
\text { income } \\
\text { country }\end{array}$ & $\begin{array}{l}48 \text { villages } \\
\text { randomly assigned } \\
\text { to an intervention or } \\
\text { control condition. } \\
\text { Women in their last } \\
\text { trimester of } \\
\text { pregnancy } \\
\text { recruited were } \\
\text { (intervention: } \\
n=163 ; \quad \text { control: } \\
n=146) .\end{array}$ & $\begin{array}{l}\text { Duration: } 6 \text { months } \\
\text { Conducted by: paraprofessionals } \\
\text { 'Learning through Play' Program. } \\
\text { Consists of a pictorial calendar depicting } 8 \\
\text { successive stages of child development from birth } \\
\text { to } 3 \text { years with accompanying information of child } \\
\text { play and other activities that promote parental } \\
\text { involvement, learning and attachment. } \\
\text { A training manual is available for community } \\
\text { workers giving tips on how to conduct individual } \\
\text { or group sessions for parents using the calendar as } \\
\text { a focus. } \\
\text { Intervention consisted of a half day workshop with } \\
\text { small group of mothers when infants were } 2 \\
\text { months old followed by fortnightly home visits } \\
\text { lasting } 15-20 \text { minutes. } \\
\text { Training } \\
\text { One full-day training workshop and a } 1 \text { hour } \\
\text { refresher training session after } 2 \text { months. Ongoing } \\
\text { monitoring and supervision provided. }\end{array}$ & $\begin{array}{l}\text { Maternal outcomes } \\
\text { Parenting: } \\
\text { Significant benefits of intervention to mother's } \\
\text { knowledge of child development. } \\
\text { Mothers'psychosocial function: } \\
\text { No significant benefits of intervention to maternal } \\
\text { mental distress. }\end{array}$ \\
\hline
\end{tabular}


Table 2 (continued): Stimulation Interventions with Disadvantaged Children and Their Families in Developing Countries

\begin{tabular}{|c|c|c|c|}
\hline Study & Sample & Intervention & Short term effects \\
\hline $\begin{array}{l}\text { Kingston, } \\
\text { Jamaica } \\
\text { Powell \& } \\
\text { Grantham- } \\
\text { McGregor, } \\
1989 \\
\\
\text { Upper- } \\
\text { middle } \\
\text { income } \\
\text { country }\end{array}$ & $\begin{array}{l}\text { Study } 1 \\
152 \text { children aged } \mathbf{6 - 3 0} \\
\text { months of low SES } \\
\text { mothers allocated to } 3 \\
\text { groups. } 139 \text { followed up: } \\
\text { biweekly }(\mathrm{n}=49) \text {, monthly } \\
(\mathrm{n}=45) \\
\text { Placebo }(\mathrm{n}=45) \\
\text { Study } 2 \\
58 \text { low SES mothers and } \\
\text { their children aged 16-30 } \\
\text { months randomized to } \\
\text { intervention }(\mathrm{E} n=29) \text { or } \\
\text { control }(\mathrm{C} \mathrm{n}=29)\end{array}$ & $\begin{array}{l}\text { Duration: } 1 \text { year and } 2 \text { years ( } 2 \text { separate samples) } \\
\text { Conducted by: Paraprofessionals } \\
\text { Study } 1 \\
\text { Biweekly or monthly visits for } 2 \text { years } \\
\text { Study } 2 \\
\text { Weekly home visits for } 1 \text { year } \\
\text { Intervention involved home visits by community health } \\
\text { aides during which the mothers were shown activities to } \\
\text { do with their child and a home made toy or a book was } \\
\text { left in the home. } \\
\text { The placebo group received toys only. } \\
\text { Training } \\
\text { Community health aides received } 1 \text { week initial training } \\
\text { and ongoing monitoring and supervision throughout the } \\
\text { intervention period. }\end{array}$ & $\begin{array}{l}\text { Child outcomes } \\
\text { Mental development: } \\
\text { Study } 1 \\
\text { Biweekly }>\text { monthly }=\text { control on DQ and performance subscale } \\
\text { Biweekly = monthly = control on hearing and speech and hand } \\
\text { and eye subscales } \\
\text { Biweekly = monthly }>\text { control on PPVT (receptive vocabulary) } \\
\text { Study } 2 \\
\text { Intervention significantly benefited overall DQ on the Griffiths } \\
\text { test and hearing \& speech and performance subscales } \\
\text { No significant benefits were found for the hand \& eye subscale } \\
\text { Intervention significantly benefited children's receptive } \\
\text { vocabulary measured by the Peabody Picture Vocabulary Test. }\end{array}$ \\
\hline $\begin{array}{l}\text { Clarendon, } \\
\text { rural } \\
\text { Jamaica } \\
\text { Powell, } \\
2004 \\
\text { Upper- } \\
\text { middle } \\
\text { income } \\
\text { country }\end{array}$ & $\begin{array}{l}163 \text { children aged } 12-\mathbf{3 0} \\
\text { months allocated to } \\
\text { intervention }(\mathrm{I} n=93) \text { or } \\
\text { control }(\mathrm{C} n=70) \\
19.6 \% \text { attrition }\end{array}$ & $\begin{array}{l}\text { Duration: } 1 \text { year } \\
\text { Conducted by: paraprofessionals (young school leavers) } \\
\text { Intervention involves weekly home visits to demonstrate } \\
\text { and teach mothers play activities they can do with their } \\
\text { children. Parent meetings are also held and income } \\
\text { generating projects are supported. } \\
\text { Training } \\
\text { Initial training followed by half-day training sessions } \\
\text { once per fortnight and ongoing supervision and } \\
\text { monitoring. }\end{array}$ & $\begin{array}{l}\text { Child outcomes } \\
\text { Mental development: } \\
\text { Intervention benefited children's overall DQ, hand and eye and } \\
\text { performance subscales of the Griffiths test } \\
\text { No significant benefits of intervention were found on the } \\
\text { hearing and speech subscale of Griffiths test } \\
\text { Nutritional Status: } \\
\text { No significant benefits to child growth. } \\
\text { Maternal Outcomes } \\
\text { Parenting: } \\
\text { Intervention significantly benefited mothers' knowledge of child } \\
\text { care and development } \\
\text { No significant benefits of intervention on knowledge of health } \\
\text { and nutrition } \\
\text { No significant benefits to parenting practices . } \\
\text { Psychosocial function: } \\
\text { No significant benefits to parenting self-esteem }\end{array}$ \\
\hline
\end{tabular}


Table 2 (continued): Stimulation Interventions with Disadvantaged Children and Their Families in Developing Countries

\begin{tabular}{|c|c|c|c|}
\hline Study & Sample & Intervention & Short term effects \\
\hline $\begin{array}{l}\text { Rural } \\
\text { Bangladesh } \\
\text { Aboud, } \\
2007 \\
\text { Low } \\
\text { income } \\
\text { country }\end{array}$ & $\begin{array}{l}\text { Post test only } \\
\text { intervention-control } \\
\text { study design. } \\
22 \text { villages which had } \\
\text { received a parenting } \\
\text { intervention in the } \\
\text { previous year and } 22 \\
\text { villages with no } \\
\text { parenting intervention } \\
\text { were recruited. } \\
\text { Mothers of children } \\
\text { aged 2.5-4.0 years } \\
\text { were recruited. } \\
\text { Intervention: } \mathrm{n}=170 \\
\text { Control: } \mathrm{n}=159\end{array}$ & $\begin{array}{l}\text { Duration: } 1 \text { year } \\
\text { Conducted by: Paraprofessionals } \\
\text { Parenting programme implemented through PLAN } \\
\text { International. } \\
\text { Programme targeted mothers of children under } 3 \text { years and } \\
\text { involved 90-minute weekly education sessions to groups of } \\
\text { mothers. } \\
\text { Topics included common diseases, oral rehydration } \\
\text { solutions, hygiene, sanitation, breastfeeding, weaning foods, } \\
\text { micronutrient deficiencies, stages of cognitive and language } \\
\text { development, how to help children learn and encourage } \\
\text { language development, positive discipline, gender equality } \\
\text { and child rights. } \\
\text { Training } \\
17 \text { days basic training, four days a month supervision and } \\
\text { monthly refresher courses. }\end{array}$ & $\begin{array}{l}\text { Child outcomes } \\
\text { Mental development: } \\
\text { No significant benefits of intervention to children's receptive } \\
\text { vocabulary. (But there was a group x sex interaction which } \\
\text { showed that boys did better in the parenting group and girls did } \\
\text { worse). } \\
\text { Nutritional Status: } \\
\text { Children in parenting group more likely to have poorer weight } \\
\text { for height. No significant differences for weight for age. } \\
\text { Health: } \\
\text { Intervention significantly benefited preventative health } \\
\text { behaviours (e.g. using a latrine) } \\
\text { Maternal outcomes } \\
\text { Parenting: } \\
\text { Intervention significantly benefited others knowledge of child } \\
\text { development (Effect size }=0.31 \text { ). } \\
\text { Intervention significantly benefited stimulation in the home } \\
\text { (Effect size = } 0.34 \text { ) (Mothers with more assets and mothers with } \\
\text { at least one year of education benefited more from the } \\
\text { intervention). } \\
\text { No significant benefits of the programme to mother's } \\
\text { communication with child during a picture-talking task. }\end{array}$ \\
\hline $\begin{array}{l}\text { Himachal } \\
\text { Pradesh, } \\
\text { India } \\
\text { Sharma \& } \\
\text { Nagar, } \\
2009 \\
\text { Lower- } \\
\text { middle } \\
\text { income } \\
\text { country }\end{array}$ & $\begin{array}{l}145 \text { infants aged birth } \\
\text { to } \mathbf{1 8} \text { months from } 2 \\
\text { villages in Himachal } \\
\text { Pradesh. One village } \\
\text { received intervention } \\
\text { and the other village did } \\
\text { not. } \\
\text { Intervention: } \mathrm{n}=69 \\
\text { Control: } \mathrm{n}=76\end{array}$ & $\begin{array}{l}\text { Duration: } 18 \text { months } \\
\text { Conducted by: not specified } \\
\text { Age appropriate toys and play materials and suggested } \\
\text { activities. } \\
\text { Mothers provided with information regarding providing a } \\
\text { stimulating home environment and understanding children's } \\
\text { developmental milestone. } \\
\text { Training } \\
\text { Not specified }\end{array}$ & $\begin{array}{l}\text { Child outcomes } \\
\text { Mental and motor development: } \\
\text { Significant benefits of intervention to mental and motor } \\
\text { development index of the Bayley Scales of Infant Development } \\
\text { Maternal outcomes } \\
\text { Parenting: } \\
\text { Intervention significantly benefited stimulation in the home. }\end{array}$ \\
\hline
\end{tabular}


Table 2 (continued): Stimulation Interventions with Disadvantaged Children and Their Families in Developing Countries

\begin{tabular}{|c|c|c|c|}
\hline Study & Sample & Intervention & Short term effects \\
\hline $\begin{array}{l}\text { Northeast } \\
\text { Brazil } \\
\text { Eickmann } \\
\text { et al. } 2003\end{array}$ & $\begin{array}{l}\text { Sample of } 156 \text { children } \\
\text { aged } 13 \text { months from a } \\
\text { larger cohort. } \\
\text { Intervention sites ( } \mathrm{n}=78 \text { ): } \\
\text { All children with a mental } \\
\text { and/or motor development } \\
\text { index } \leq 100 \text { and equal } \\
\text { numbers of children with } \\
\text { an index of } 101-115 \text {. } \\
\text { Control sites ( } \mathrm{n}=78 \text { ): } \\
\text { Children matched for } \\
\text { developmental index and } \\
\text { sex with children in } \\
\text { intervention site. }\end{array}$ & $\begin{array}{l}\text { Duration: } 5 \text { months } \\
\text { Conducted by: occupational therapists with } \\
\text { specializations in child development for workshops and } \\
\text { paraprofessionals for home visits. } \\
\text { Intervention involved workshops and home visits and } \\
\text { involved a total of } 14 \text { contacts between } 13 \text { and } 17 \text { months } \\
\text { of age: } 11 \text { home visits and } 3 \text { workshops. } \\
\text { During the workshops mothers practiced playing and } \\
\text { interacting with children, made toys from discarded } \\
\text { materials, and learned how to integrate stimulation } \\
\text { activities into regular activities. (Refreshments and } \\
\text { transportation were provided). } \\
\text { Home visits involved showing the mother how to engage } \\
\text { her child in play activities. } \\
\text { Training } \\
\text { Not specified }\end{array}$ & $\begin{array}{l}\text { Child outcomes } \\
\text { Mental and motor development: } \\
\text { Intervention significantly benefited child mental and motor } \\
\text { development on the Bayley test }(\text { Effect size }=>0.5) \text {. } \\
\text { Children with IQ } \leq 100 \text { benefited more (effect size=1) than } \\
\text { children with IQ }>100(\text { effect size }=0.55) \text {. }\end{array}$ \\
\hline $\begin{array}{l}\text { Rural China } \\
\text { Jin et al. } \\
2007 \\
\text { Lower- } \\
\text { middle } \\
\text { income } \\
\text { country }\end{array}$ & $\begin{array}{l}\begin{array}{l}\text { Sample of } 100 \\
\text { families } \\
\text { with a child younger } \\
\text { than } 2 \text { years } \\
\text { randomly } \\
\text { from } 7 \\
\text { villages. }\end{array} \\
\begin{array}{l}\text { Families } \\
\text { allocated to intervention } \\
(n=50) \text { or to a control }\end{array} \\
\text { condition }(n=50) \text {. }\end{array}$ & $\begin{array}{l}\text { Duration: } 2 \text { sessions over } 6 \text { months } \\
\text { Conducted by: Counsellors (qualifications not stated) } \\
\text { Two counseling sessions lasting } 30-60 \text { minutes using the } \\
\text { WHO 'Care for Development' guidelines. } \\
\text { Mothers were given a card (Mother's Card) depicting age- } \\
\text { specific messages for promotion of effective play and } \\
\text { communication between caregiver and child. The card was } \\
\text { discussed in the two counseling sessions using } \\
\text { demonstration and practice. Sessions also involved } \\
\text { discussing obstacles and providing recommendations and } \\
\text { help with problem solving issues relating to child } \\
\text { development. } \\
\text { Training } \\
\text { Not specified }\end{array}$ & $\begin{array}{l}\text { Child outcomes } \\
\text { Mental and motor development: } \\
\text { Intervention significantly benefited Gessell Development scores } \\
\text { including the motor, adaptive, language and social scales } \\
\text { (Effect size = approx 0.67). } \\
\text { (analysis did not control for covariates) } \\
\text { Maternal outcomes } \\
\text { Parenting: } \\
\text { Intervention mothers showed increased understanding of the } \\
\text { child development messages in the 'Mother's Card' and more } \\
\text { mothers in the intervention group reported that the messages } \\
\text { were feasible than mothers in the control group. }\end{array}$ \\
\hline
\end{tabular}


Table 2 (continued): Stimulation Interventions with Disadvantaged Children and Their Families in Developing

\section{Countries}

\begin{tabular}{|c|c|c|c|}
\hline Study & Sample & Intervention & Short term effects \\
\hline $\begin{array}{l}\text { Ankara, } \\
\text { Turkey }\end{array}$ & $\begin{array}{l}\text { Sequentially conducted } \\
\text { controlled trial. }\end{array}$ & $\begin{array}{l}\text { Duration: } 2 \text { weeks } \\
\text { Conducted by: Pediatricians }\end{array}$ & $\begin{array}{l}\text { Effects after } 1 \text { month: } \\
\text { Maternal outcomes } \\
\text { Parenting: }\end{array}$ \\
\hline $\begin{array}{l}\text { Ertem et al. } \\
2006 \\
\text { Upper- } \\
\text { middle } \\
\text { income }\end{array}$ & $\begin{array}{l}\text { Children aged } \leq \mathbf{2 4} \\
\text { months attending clinic } \\
\text { with minor or no illness } \\
\text { Intervention: } \mathrm{n}=120 \\
\text { Control: } \mathrm{n}=113\end{array}$ & $\begin{array}{l}\text { 'Care for Development' intervention conducted by } \\
\text { pediatricians during } 2 \text { clinic visits } 1 \text { week apart. } \\
\text { The Care for development intervention involves using an } \\
\text { interview to assess how the caregiver plays and } \\
\text { communicates with her child and then discussing } \\
\text { appropriate strategies to promote positive mother-child }\end{array}$ & $\begin{array}{l}\text { No significant differences between intervention and control } \\
\text { groups on total stimulation in the home (HOME scale) } \\
\text { Significantly more families in the intervention group had } \\
\text { HOME scores } \geq 38 \text { compared to the control group. } \\
\text { (Significant predictors of HOME were intervention group, child } \\
\text { age }>6 \text { months and higher maternal education). }\end{array}$ \\
\hline country & $\begin{array}{l}\text { Low and middle income } \\
\text { children living in Ankara } \\
\text { were selected. }\end{array}$ & $\begin{array}{l}\text { interaction and appropriate play activities. Mothers were } \\
\text { also encouraged to read picture books to their child. } \\
\text { Training } \\
\text { Not specified }\end{array}$ & $\begin{array}{l}\text { Significantly more home-made toys in intervention group } \\
\text { Significantly more caregivers reported reading to their children } \\
\text { in the intervention group } \\
\text { No significant differences in compliance with medical treatment } \\
\text { and illness outcomes. }\end{array}$ \\
\hline $\begin{array}{l}\text { South } \\
\text { Africa } \\
\text { Magwaza } \\
\text { \& Edwards, } \\
1991 \\
\text { Upper- } \\
\text { middle } \\
\text { income } \\
\text { country }\end{array}$ & $\begin{array}{l}90 \text { 4-year old children } \\
\text { from low SES families } \\
\text { randomly assigned to } \\
\text { intervention }(n=30) \text {, home } \\
\text { visits only }(n=30) \text { or a } \\
\text { control group }(n=30)\end{array}$ & $\begin{array}{l}\text { Duration: } 10 \text { weeks } \\
\text { Conducted by: research assistants } \\
\text { Intervention involved a } 10 \text {-week home visiting programme } \\
\text { focusing on verbal stimulation. } \\
\text { The intervention involved role-playing mother child } \\
\text { interaction using pictures and toys to the mother and then } \\
\text { asking the mother to use the demonstrated techniques. } \\
\text { Mothers were observed and feedback was given on their } \\
\text { interaction. After the feedback, mothers were again } \\
\text { encouraged to interact with their child and further } \\
\text { feedback was given. } \\
\text { The toys and/or books were left in the home and mothers } \\
\text { were encouraged to use the material daily. } \\
\text { Training: Extensive }\end{array}$ & $\begin{array}{l}\text { Child outcomes } \\
\text { IQ: } \\
\text { Intervention significantly benefited child IQ on the Cattell } \\
\text { Culture Fair intelligence Test compared to the two comparison } \\
\text { groups. } \\
\text { Child Behaviour: } \\
\text { Intervention significantly benefited children's task-oriented } \\
\text { behaviour, positive social behaviour and distractible behaviour. }\end{array}$ \\
\hline
\end{tabular}


Table 2 (continued): Stimulation Interventions with Disadvantaged Children and Their Families in Developing

\section{Countries}

\begin{tabular}{|c|c|c|c|c|}
\hline Study & Sample & Intervention & Short term effects & Long term effects \\
\hline $\begin{array}{l}\text { Klein \& } \\
\text { Rye, 2004 } \\
\text { Ethiopia } \\
\text { Low } \\
\text { income } \\
\text { country }\end{array}$ & $\begin{array}{l}2 \text { poor communities in } \\
\text { Addis Ababa, } \\
\text { Ethiopia. } \\
\text { Quasi-experimental } \\
\text { Systematic random } \\
\text { sampling of } 49 / 893 \\
\text { families from one } \\
\text { community and } \\
47 / 1997 \text { families in } \\
\text { another community. } \\
\text { Two communities } \\
\text { randomly assigned to } \\
\text { intervention } \\
\text { control. or } \\
\text { Children were } \mathbf{1 - 3} \\
\text { years old. }\end{array}$ & $\begin{array}{l}\text { Duration: } 3 \text { months } \\
\text { Conducted by: Paraprofessionals } \\
\text { (but } 12 \text { years of schooling) } \\
\text { Intervention involved 'The } \\
\text { Mediational Intervention for } \\
\text { Sensitizing Caregivers' (MISC). } \\
\text { The intervention involved } \\
\text { videotaping maternal-child } \\
\text { interactions and focusing on } \\
\text { strengthening the positive aspects } \\
\text { of the interaction. Also role plays, } \\
\text { presentation of good and bad } \\
\text { examples of mediation and } \\
\text { promoting generalization. } \\
\text { Five home visits ( } 11 / 2 \text { hours each) } \\
\text { by paraprofessionals and five group } \\
\text { meetings (2-3 hours) were held } \\
\text { over a } 3 \text { month period. } \\
\text { Training } \\
\text { Paraprofessionals received weekly } \\
\text { or biweekly training sessions for } 2 \\
\text { months and the trainees had to pass } \\
\text { practical and theoretical training } \\
\text { criteria before commencing with } \\
\text { the intervention. }\end{array}$ & $\begin{array}{l}\text { Child outcomes } \\
\text { Mental development: } \\
\text { Significant benefits of } \\
\text { intervention to child language } 1 \\
\text { year after the end of the } \\
\text { intervention period. } \\
\text { Mother-child interaction } \\
\text { Significant benefits of } \\
\text { intervention to mother-child } \\
\text { interactions (both parent and } \\
\text { child initiated) at } 3 \text { months and } \\
1 \text { year after the end of the } \\
\text { intervention }\end{array}$ & $\begin{array}{l}\text { At } 6 \text { year follow up: } \\
\text { Child outcomes } \\
\text { Child Behaviour: } \\
\text { children in the intervention group were } \\
\text { rated by their mothers as: } \\
\text { Less hostile and aggressive, } \\
\text { Less anxious } \\
\text { Less hyperactive and } \\
\text { Less distractible } \\
\text { than children in the comparison group } \\
\text { Mother-child interaction } \\
\text { Significant benefits of intervention to } \\
\text { mother-child interactions. }\end{array}$ \\
\hline
\end{tabular}


Table 2 (continued): Stimulation Interventions with Disadvantaged Children and Their Families in Developing

Countries

\begin{tabular}{|c|c|c|c|}
\hline Study & Sample & Intervention & Short term effects \\
\hline $\begin{array}{l}\text { Vietnam } \\
\text { Watanabe } \\
\text { et al. } 2005 \\
\text { Low } \\
\text { income } \\
\text { country }\end{array}$ & $\begin{array}{l}313 \text { children aged } \\
4-5 \text { years from two } \\
\text { rural communes. } \\
\text { Both communes } \\
\text { had participated in } \\
\text { a nutrition } \\
\text { intervention from } \\
\text { birth to three years. } \\
\text { One commune with } \\
\text { poorer preschool } \\
\text { facilities also } \\
\text { received an ECD } \\
\text { intervention when } \\
\text { the children were } \\
\text { aged } 4-5 \text { years and } \\
\text { one commune did } \\
\text { not. }\end{array}$ & $\begin{array}{l}\text { Duration: } 3 \text { years } \\
\text { Conducted by: not specified } \\
\text { Intervention involved strengthening existing } \\
\text { preschools through material support and teacher } \\
\text { training. } \\
\text { Parenting sessions were also instituted including } 1 \\
\text { day training seminars with father and mothers } \\
\text { separately once a month for } 10 \text { months. } \\
\text { A local library was developed and play corners were } \\
\text { promoted in homes. } \\
\text { Training } \\
\text { Not specified }\end{array}$ & $\begin{array}{l}\text { Child outcomes } \\
\text { IQ: } \\
\text { Intervention significantly benefited } \\
\text { child IQ on Raven's Progressive } \\
\text { matrices. } \\
\text { Stunted children benefited more than } \\
\text { non-stunted children (Effect size } 0.61 \\
\text { and } 0.06 \text { respectively). }\end{array}$ \\
\hline
\end{tabular}


Table 2 (continued): Stimulation Interventions with Disadvantaged Children and Their Families in Developing

Countries

\begin{tabular}{|c|c|c|c|c|}
\hline Country & Study Design & Intervention & Concurrent Effects & Long-term Effects \\
\hline $\begin{array}{l}\text { Turkey } \\
\text { Kagitcibasi et } \\
\text { al. 2001, 2009 } \\
\text { Upper-middle } \\
\text { income } \\
\text { country }\end{array}$ & $\begin{array}{l}255 \text { children from low } \\
\text { SES backgrounds aged } \\
\text { 3-5 years. } \\
6 \text { groups: } \\
\text { 1. Custodial day care } \\
\text { 2. Custodial day care } \\
\text { and mother training } \\
\text { 3. Educational day care } \\
\text { 4. Educational day care } \\
\text { \& mother training } \\
\text { 5. No day care } \\
\text { 6. No day care \& } \\
\text { mother training }\end{array}$ & $\begin{array}{l}\text { Duration: } 2 \text { years } \\
\text { Conducted by: Paraprofessionals } \\
\text { Mother training involved } \\
\text { fortnightly home visits and } \\
\text { fortnightly group meetings. } \\
\text { Group meetings lasted approx } 1 \\
\text { hour and were conducted by } \\
\text { trained paraprofessionals (local } \\
\text { coordinators). Meetings included } \\
\text { discussions of topics related to } \\
\text { child development (e.g. nutrition, } \\
\text { child health, child development, } \\
\text { play activities, discipline, and } \\
\text { preschool communication). } \\
\text { Home visits were conducted by } \\
\text { 'mother's aides similar in } \\
\text { education and SES to the } \\
\text { mothers. They delivered the } \\
\text { materials to the mothers and } \\
\text { demonstrated their use. Mother's } \\
\text { aides also visited mothers during } \\
\text { the group meetings to } \\
\text { demonstrate use of the cognitive } \\
\text { materials. } \\
\text { Training } \\
\text { Local coordinators received } 1 \\
\text { week initial training program and } \\
\text { periodic further training and } \\
\text { feedback throughout the } 2 \text { years. } \\
\text { Mother's aides were trained } \\
\text { weekly by the local coordinators } \\
\text { and their performance monitored }\end{array}$ & $\begin{array}{l}\text { After 1 year: } \\
\text { Child Outcomes } \\
\text { IQ } \\
\text { Significant benefits of } \\
\text { educational day care and mother } \\
\text { training on child IQ. } \\
\text { Schooling: } \\
\text { No significant benefits of } \\
\text { educational day care or mother } \\
\text { training on academic achievement } \\
\text { tests. } \\
\text { Significant benefits } \\
\text { educational day care and mother } \\
\text { training on school grades. } \\
\text { Behavior } \\
\text { No significant benefits of } \\
\text { educational day care or mother } \\
\text { training on emotional problems or } \\
\text { school adjustment. } \\
\text { Significant benefits of mother } \\
\text { training on child aggression. } \\
\text { Maternal outcomes } \\
\text { Parenting: } \\
\text { Mothers who had received } \\
\text { training reported interacting with } \\
\text { their child more, conducting more } \\
\text { cognitively stimulating activities } \\
\text { and helping children with their } \\
\text { homework more. } \\
\text { Mothers who had received } \\
\text { training reported using less } \\
\text { punitive discipline methods. }\end{array}$ & $\begin{array}{l}6 \text { year follow up } \\
\text { Child outcomes } \\
\text { IQ: } \\
\text { Mother training and educational day } \\
\text { care significantly benefited WISC-R } \\
\text { vocabulary test. } \\
\text { Schooling: } \\
\text { Mother training significantly benefited } \\
\text { school achievement } \\
\text { Maternal outcomes } \\
\text { Life course: } \\
\text { Mother training significantly benefited } \\
\text { mother's status in the family and } \\
\text { general family relations. } \\
\text { 22 year follow up } \\
\text { Child outcomes } \\
\text { IQ: } \\
\text { No significant effects of mother } \\
\text { training or educational day care on } \\
\text { child IQ. } \\
\text { Schooling: } \\
\text { Trend for increased college attendance } \\
\text { in the mother training group. } \\
\text { Enrichment benefited boys more than } \\
\text { girls. } \\
\text { Socio-Economic domain: } \\
\text { No significant effect of mother } \\
\text { training on later employment. } \\
\text { Educational day care significantly } \\
\text { benefited participants' occupational } \\
\text { status. } \\
\text { Children in the lowest quartile for } \\
\text { child IQ on enrolment did not benefit } \\
\text { from early stimulation. }\end{array}$ \\
\hline
\end{tabular}




\section{Stimulation Only Interventions with Undernourished Children and Their Families}

Five studies describing stimulation only interventions that specifically targeted undernourished children and their families were identified- three from Jamaica (an upper middle income country) and two from Bangladesh (a low income country). The studies are described in Table 3 . Three of the studies were randomized controlled trials (Hamadani et al. 2006, Powell et al. 2004, Walker et al. 2004) while two were quasi-experimental (Grantham-McGregor et al. 1987, Nahar et al. 2009). All studies involved home visiting although the study by Hamadani and colleagues (2006) supplemented the home visiting with group sessions with mothers. Two of the studies intervened with severely malnourished children and the stimulation interventions began while the child was in hospital and was continued after hospital discharge through home visiting (Grantham-McGregor et al. 1987, Nahar et al. 2009). Two studies involved undernourished children in the community (Hamadani et al. 2006, Powell et al. 2004) and one study children born term low birth weight. Four of the studies intervened with children beginning at a relatively wide age range (e.g. from age 6-24 months) and in the study with term low birth weight children the intervention started from birth (Walker et al. 2004) (This study was also included in Table 1).

All five studies used a similar curriculum which involved demonstrating play activities to the mother and encouraging her to do the activity with her child. Home-made toys and books were used in addition to items in the home. Emphasis was also placed on encouraging positive maternal-child interactions and on building mothers' confidence and self-esteem. The curriculum was delivered by paraprofessionals in all studies. The duration of the interventions varied from 6 months to 3 years.

\section{Child Outcomes}

\section{Child IQ}

All studies measured children's mental development and all found benefits. Two studies included a longer-term follow up. Severely malnourished children who had received stimulation for three years were found to have significantly higher IQ than non-stimulated children 11 years after the end of the intervention (Grantham-McGregor et al. 1994), although their scores were 
significantly below a matched group of children who had not been undernourished in early childhood (Figure 2).

Figure 2. Developmental levels of severely malnourished Jamaican children until adolescence

$\mathrm{DQ} / \mathrm{IQ}$ z-scores

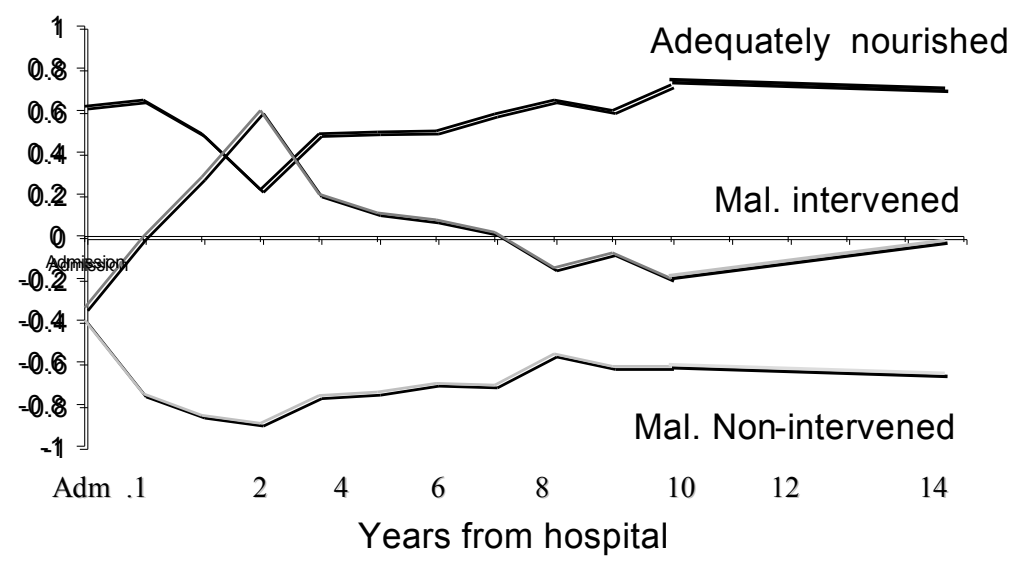

Grantham-McGregor et al, 1994

Low birth weight infants born at term who had received stimulation for two years had significantly higher scores on performance IQ and visual-spatial memory than non-stimulated infants (Walker et al. 2010) although no significant benefits were found to full IQ, receptive vocabulary or attention.

Concurrent benefits to children's motor development were found in two of the five studies and both of these studies targeted children who were severely malnourished on enrolment (GranthamMcGregor et al. 1983, Nahar et al. 2009).

\section{Child Behavior}

Four studies measured child behavior and three found benefits. The study by GranthamMcGregor and colleagues (1987) with severely malnourished children found that, at the end of the three years of intervention, children who had not received stimulation stayed closer to their mother and stopped play sooner than the children who had received stimulation. The study by Hamadani and colleagues (2006) with underweight children found benefits to children behaviour during the developmental test session after one year of intervention. Walker and colleagues (2010) reported benefits to children's total behavior difficulties on the Strengths and Difficulties 
Questionnaire at age six for children who had received 2 years of intervention starting at birth. Nahar and colleagues (2009) however found no benefits of stimulation to children's behaviour during the developmental test session although this intervention lasted only six months.

\section{Child Nutritional Status}

All five studies measured examined the effects of stimulation on child growth and only one study found benefits. Severely malnourished children who received stimulation for two weeks in hospital followed by six months of stimulation through home-visiting had significantly greater weight for age scores than a matched control group (Nahar et al. 2009).

\section{Child Schooling}

Two studies examined the effects of stimulation in early childhood on child schooling. Grantham-McGregor and colleagues (1994) found no significant benefits eleven years after the end of the intervention period and Walker and colleagues (2010) found no benefits to children's reading ability four years after the end of the intervention when the children were six years old.

\section{Child Health}

No studies included child health outcomes.

\section{Maternal Outcomes}

\section{Parenting}

Four studies evaluated the effect of intervention on parenting and three found benefits. Two studies found benefits to mothers' knowledge of child development (Hamadani et al. 2006, Powell et al. 2004) and one also reported benefits to mother reports of parenting practices (Powell et al. 2004). One study reported the benefits of intervention to the level of stimulation provided in the home assessed through a combination of maternal report and direct observation (Walker et al. 2004). However, Grantham-McGregor and colleagues (1989) found no differences in structured observations of maternal behaviour between the intervention and control groups.

\section{Maternal Psychosocial Function}

One study evaluated the effect of intervention on maternal psychosocial function. A randomized trial of a home-visiting intervention for underweight Jamaican children conducted over one year resulted in significant reductions in maternal depression (Baker-Henningham et al. 2005). 


\section{Maternal Life Course and Mother-Child Interaction}

No studies investigated the effect of intervention on maternal life-course or maternal-child interaction.

\section{Summary of Stimulation Only Interventions with Undernourished Children}

The studies provide robust evidence that early stimulation can benefit the mental development of undernourished children over the short term. There is also some evidence that interventions with severely malnourished children benefit children's concurrent motor development although the studies with moderately undernourished children showed no benefits to child motor development. The evidence regarding child behaviour is more mixed although interventions of sufficient duration (at least 1 year) have shown benefits. Only one study found benefits to child growth which suggests that stimulation alone is usually insufficient to benefit the growth of undernourished children and nutritional supplementation is also required. There is insufficient evidence from the studies reviewed as to whether early stimulation can benefit children's schooling trajectories or child health.

There is some evidence that mothers' parenting behaviours improve with early stimulation through home visiting although this was not found in one of the four studies that measured it. There is also some evidence of benefits to maternal mental health. Only one study included long term outcomes and benefits to child cognition were sustained. 
Table 3: Stimulation Only Interventions with Undernourished Children and Their Families in Developing Countries

\begin{tabular}{|c|c|c|c|c|}
\hline Country & Study Design & Intervention & Concurrent Effects & Long-term Effects \\
\hline $\begin{array}{l}\text { Jamaica } \\
\text { Grantham- } \\
\text { McGregor } \\
\text { et al. 1983, } \\
1987,1989 \text {, } \\
1994 \\
\text { Upper- } \\
\text { middle } \\
\text { income } \\
\text { country }\end{array}$ & $\begin{array}{l}3 \text { groups in hospital } \\
\text { aged } \mathbf{6}-\mathbf{2 4} \\
\text { months. } \\
\text { Control: severely } \\
\text { malnourished with } \\
\text { standard care ( } \mathrm{n}= \\
\text { 18) } \\
\text { 1 year later: } \\
\text { Intervention: } \\
\text { severely } \\
\text { malnourished with } \\
\text { stimulation (n }= \\
\text { 16) }\end{array}$ & 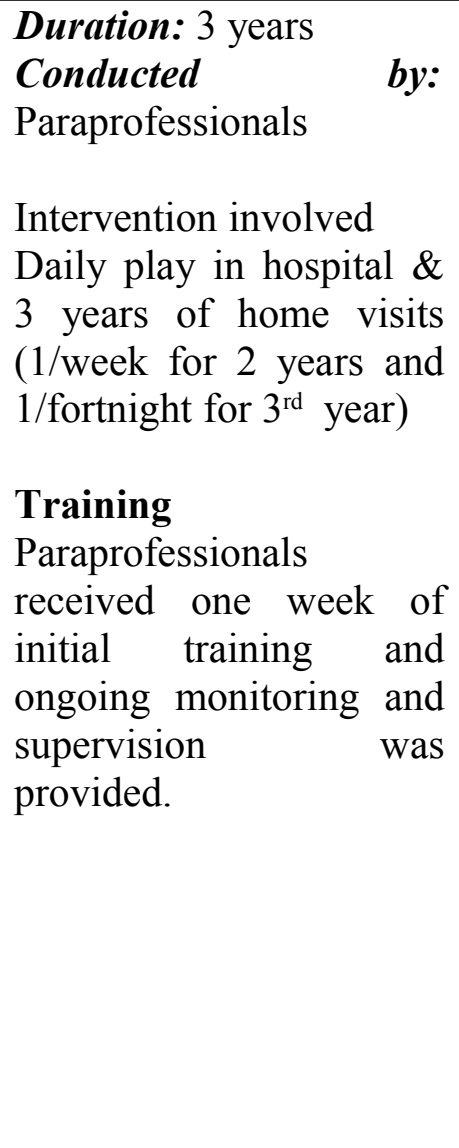 & $\begin{array}{l}\text { Child outcomes } \\
\text { Mental and motor } \\
\text { development: } \\
24 \text { months after leaving } \\
\text { hospital: the overall DQ of } \\
\text { children in the intervention } \\
\text { group was significantly better } \\
\text { than the control group. } \\
\text { Intervention children also had } \\
\text { significantly higher IQ than } \\
\text { control children } 60 \text { \& } 72 \\
\text { months after leaving hospital. } \\
\text { Behaviour: } \\
\text { Control children stayed closer } \\
\text { to mother and stopped play } \\
\text { sooner than intervention } \\
\text { children and after } 3 \text { years of } \\
\text { study } \\
\text { Maternal outcomes } \\
\text { Parenting: } \\
\text { No benefits of intervention to } \\
\text { mothers' interaction with her } \\
\text { child }\end{array}$ & $\begin{array}{l}\text { Child outcomes at } 14 \text { year follow-up } \\
\text { IQ: } \\
\text { Intervention children had significantly } \\
\text { higher WISC full scale IQ \& verbal } \\
\text { subscale. } \\
\text { No significant benefits of intervention } \\
\text { to the WISC performance subscale or to } \\
\text { children's performance on the Peabody } \\
\text { Picture Vocabulary Test. } \\
\text { Schooling: } \\
\text { No significant benefits of intervention } \\
\text { to school achievement } \\
\text { Nutritional status: } \\
\text { No significant benefits of intervention } \\
\text { to nutritional status at age } 13 \text { years }\end{array}$ \\
\hline
\end{tabular}


Table 3 (continued): Stimulation Only Interventions with Undernourished Children and Their Families in Developing

Countries

\begin{tabular}{|c|c|c|c|}
\hline Study & Sample & Intervention & Short term effects \\
\hline $\begin{array}{l}\text { Rural } \\
\text { Bangladesh } \\
\text { Hamadani et } \\
\text { al. } 2006 \\
\text { Low income } \\
\text { country }\end{array}$ & $\begin{array}{l}20 \text { community nutrition } \\
\text { centres randomized to } \\
\text { intervention }(n=10) \text { or } \\
\text { control condition }(n=10) \text {. } \\
206 \text { undernourished children } \\
\text { (<-2z scores WAZ) aged 6- } \\
\mathbf{2 4} \text { months were enrolled. } \\
\text { E } n=104 \\
C \text { n=102 }\end{array}$ & $\begin{array}{l}\text { Duration: } 1 \text { year } \\
\text { Conducted by: Paraprofessionals } \\
\text { Weekly group meetings at the nutrition } \\
\text { centres for } 10 \text { months followed by meetings } \\
\text { every } 2 \text { weeks for } 2 \text { months. Topics included } \\
\text { child development and play. } \\
\text { In addition, home visits twice a week for } 8 \\
\text { months and weekly for } 4 \text { months. During the } \\
\text { home visits, the play leaders demonstrated } \\
\text { play activities using home-made toys and } \\
\text { promoted positive mother-child interaction. } \\
\text { All undernourished children received } \\
\text { standard nutrition care and supplementation. } \\
\text { Training } \\
\text { Initial training not specified. Ongoing } \\
\text { monitoring and supervision. }\end{array}$ & $\begin{array}{l}\text { Child Outcomes } \\
\text { Mental and motor development: } \\
\text { Significant benefits of intervention on the mental development } \\
\text { index of the Bayley test } \\
\text { No significant benefits of intervention on the psychomotor } \\
\text { development index of the Bayley test (but children who received } \\
\text { more home visits had higher scores). } \\
\text { Nutrition: } \\
\text { No significant effect of intervention on growth } \\
\text { Behavior: } \\
\text { Significant benefits of intervention to response to examiner, } \\
\text { cooperation, emotional tone and vocalization. } \\
\text { Maternal outcomes } \\
\text { Parenting: } \\
\text { Intervention had significant benefits to maternal knowledge of child } \\
\text { rearing } \\
\text { No significant benefits of intervention to maternal knowledge of } \\
\text { health and hygiene }\end{array}$ \\
\hline $\begin{array}{l}\text { Dhaka, } \\
\text { Bangladesh } \\
\text { Nahar et al. } \\
2009 \\
\text { Low income } \\
\text { country }\end{array}$ & $\begin{array}{l}\text { Severely malnourished } \\
\text { children aged 6-24 months: } \\
\text { Intervention group }(n=77) \\
\text { Control group ( } \mathrm{n}=56) \\
\text { Time-lagged controlled } \\
\text { study - control group were } \\
\text { studied 1 year prior to the } \\
\text { intervention group. } \\
33 / 77 \text { intervention children } \\
\text { followed up }(43 \%) \text {. } \\
37 \text { out of } 56 \text { control children } \\
\text { followed up }(66 \%) \text {. }\end{array}$ & $\begin{array}{l}\text { Duration: } 6 \text { months } \\
\text { Conducted by: Paraprofessionals } \\
\text { Daily } 30 \text { minute group meetings and } \\
\text { individual } 30 \text { minute play sessions for } \\
\text { mothers and children for } 2 \text { weeks in hospital. } \\
11 \text { home visits over a } 6 \text { month period when } \\
\text { children were discharged from hospital. } \\
\text { During the home visits and hospital sessions } \\
\text { mothers were shown how to use everyday } \\
\text { activities to promote child development and } \\
\text { were also shown play activities with home- } \\
\text { made toys. } \\
\text { Training } \\
2 \text { weeks initial training and ongoing } \\
\text { monitoring and supervision. }\end{array}$ & $\begin{array}{l}\text { Child outcomes: } \\
\text { Mental and motor development: } \\
\text { Intervention significantly benefited children's motor and mental } \\
\text { development on the Bayley Scales of Infant Development (Effect } \\
\text { size } 0.52 \text { in mental development, } 0.37 \text { in motor development). } \\
\text { Behavior } \\
\text { No significant benefits of intervention to children's behaviour } \\
\text { during the developmental test session. } \\
\text { Nutrition: } \\
\text { Significant benefits of intervention to children's weight for age. }\end{array}$ \\
\hline
\end{tabular}


Table 3 (continued): Stimulation Only Interventions with Undernourished Children and Their Families in Developing Countries

\begin{tabular}{|c|c|c|c|}
\hline Study & Sample & Intervention & Short term effects \\
\hline $\begin{array}{l}\text { Kingston, } \\
\text { Jamaica } \\
\text { Powell et al. } \\
2004 \\
\text { Baker- } \\
\text { Henningham } \\
\text { et al. 2005 } \\
\text { Upper-middle } \\
\text { income } \\
\text { country }\end{array}$ & $\begin{array}{l}139 \text { undernourished children } \\
(<-1.5 \mathrm{z} \text { scores WAZ) aged } \\
\text { 9-30 months randomized by } \\
\text { clinic to intervention }(\mathrm{E} \mathrm{n}= \\
70) \text { or control }(\mathrm{C} \mathrm{n}=69) \\
7.2 \% \text { attrition } \\
\text { Both groups received } \\
\text { standard nutrition and health } \\
\text { care. }\end{array}$ & $\begin{array}{l}\text { Duration: } 1 \text { year } \\
\text { Conducted by: Paraprofessionals } \\
\text { Intervention involved weekly home visits } \\
\text { by community health aides working in } \\
\text { government health centres. The visits } \\
\text { involved demonstrating play activities with } \\
\text { mothers and discussing parenting issues. } \\
\text { Home made toys and pictures, low cost } \\
\text { books and household materials were used } \\
\text { for the play activities. } \\
\text { Training } \\
\text { Paraprofessionals received one week of } \\
\text { initial training and a two day refresher } \\
\text { training after } 6 \text { months. Ongoing } \\
\text { monitoring and supervision was provided. }\end{array}$ & $\begin{array}{l}\text { Child outcomes } \\
\text { Mental and motor development: } \\
\text { Significant benefits of intervention to Griffiths DQ and } \\
\text { hearing \& speech, hand \& eye and performance subscales. } \\
\text { (Effect size }=0.8 \text { on DQ). } \\
\text { No significant benefits to the motor subscale of the Griffiths } \\
\text { Test. } \\
\text { Nutrition: } \\
\text { No significant effect of intervention on growth } \\
\text { Maternal outcomes } \\
\text { Parenting: } \\
\text { Intervention significantly benefited parenting knowledge and } \\
\text { parenting practices } \\
\text { Psychosocial function: } \\
\text { Intervention significantly benefited maternal depressive } \\
\text { symptoms (Effect size }=0.43 \text { ) } \\
\text { Mothers receiving } 40-50 \text { visits benefited more than mothers } \\
\text { receiving } 25-39 \text { visits. Mothers receiving less than } 25 \text { visits } \\
\text { were not significantly different from the control group on } \\
\text { depressive symptoms. } \\
\text { Change in parenting knowledge and practices and change in } \\
\text { depression did not mediate the effect of intervention on child } \\
\text { development. }\end{array}$ \\
\hline
\end{tabular}


Table 3 (continued): Stimulation Only Interventions with Undernourished Children and Their Families in Developing

Countries

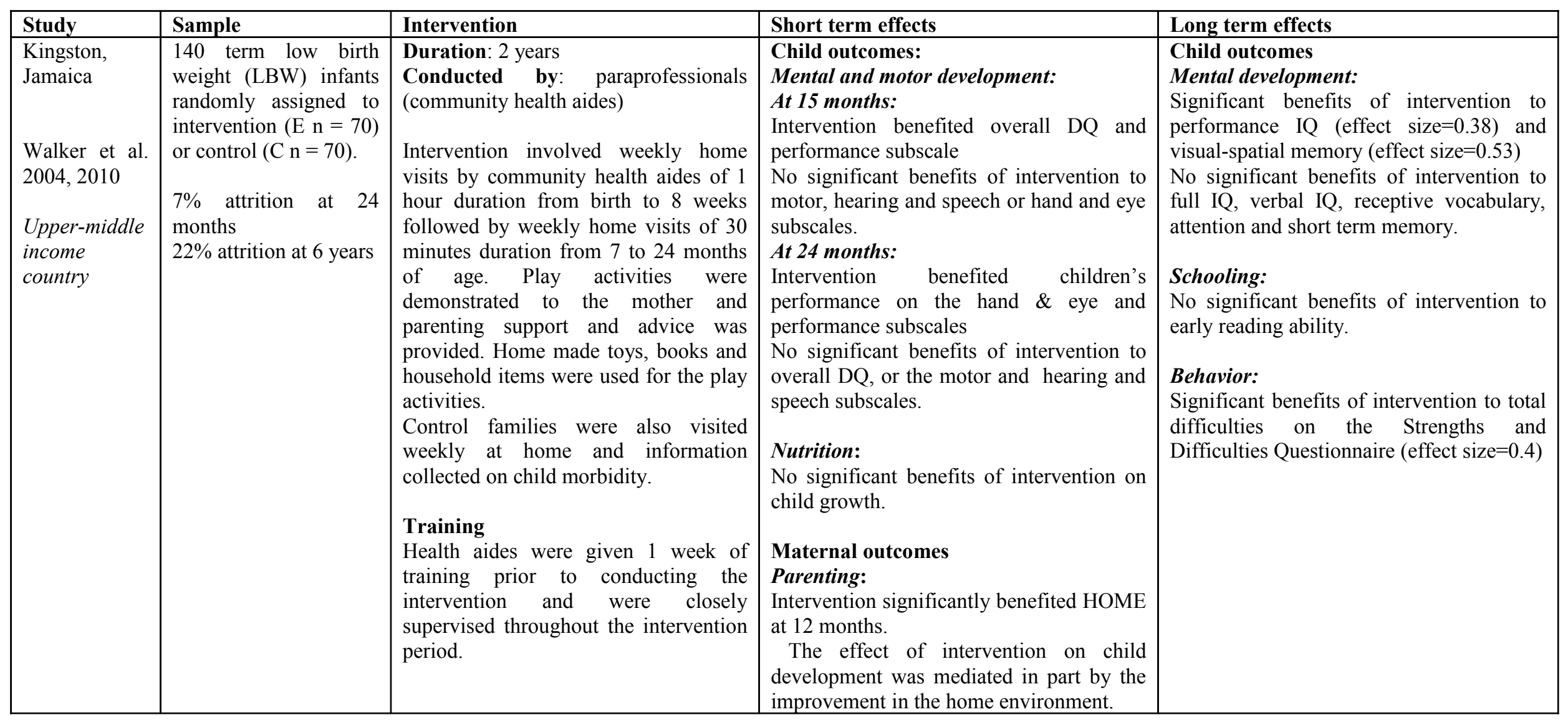




\section{Combined Nutrition and Stimulation Interventions with Children and Their Families}

Only three studies that examined the effect of a combined nutrition and stimulation intervention for young children were identified and all three were conducted in an upper-middle income country and involved a randomized design. The studies are described in detail in Table 4. The interventions were primarily delivered by paraprofessionals in all three studies. In one study, the intervention was conducted over 2 years (Grantham-McGregor et al. 1991), in one over 3 years (Waber et al. 1981) and one compared the effect of different durations of intervention on child development (McKay et al. 1978). The age of the children also differed with one study recruiting children age 9-24 months (Grantham-McGregor et al. 1991), one recruiting children from birth (Waber et al. 1981) and one recruiting children between the ages of three to six years (McKay et al. 1978). In two studies the stimulation intervention involved home-visiting by paraprofessionals (Grantham-McGregor et al. 1991, Waber et al. 1981) and the studies were designed to evaluate the effect of nutritional supplementation alone, stimulation alone, a combination of supplementation and stimulation to a control group who received neither supplementation nor stimulation. In one study, children attended a centre based service which provided nutritional supplementation and an educational component and hence it is not possible to isolate the effect of stimulation alone (McKay et al. 1978). In the latter study, the duration of the intervention and the age of the child on enrolment varied.

\section{Child Outcomes}

\section{Child Mental and Motor Development}

In the two studies that included a stimulation alone group, significant benefits of stimulation were found to children's mental development over the short term (Grantham-McGregor et al. 1991, Waber et al. 1981). In Jamaica, the benefits of stimulation to child IQ were sustained until age 17-18 years (Walker et al. 2005). Concurrent benefits of stimulation were also found to children's motor development in these two studies (Grantham-McGregor et al. 1991, Waber et al. 1981).

Nutritional supplementation benefited children's motor and mental development over the short term in the Jamaican and Bogota studies. In Jamaica, some benefit of supplementation to child IQ was still evident at age 7-8 years (especially for children of mothers with higher verbal 
IQ), but these benefits were not maintained at age 11-12 years (Walker et al. 2000) or at age 1718 years (Walker et al. 2005).

In Cali, Colombia, the child IQ scores were higher with greater duration of the combined stimulation and supplementation intervention at age 8 years (McKay et al. 1978).

\section{Child behavior}

In the Jamaica study no benefits to child behaviour from early stimulation were found for structured observations of child activity levels, amount of exploration and affect after 6 months of intervention (Meeks-Gardner 1995, 1999), or for parent reports of behaviour at age 11-12 years (Chang et al. 2002). However, significant benefits were found to participants' self-reports of mental health at age 17-18 years. Adolescents who had participated in the stimulation intervention in early childhood were less depressed, less anxious, and had higher self-esteem than adolescents who had not received stimulation (Walker et al. 2006). They also had less parentreported attention problems (Walker et al. 2006). In Bogota, Colombia, infants receiving stimulation cried less at age 4 months than infants who did not receive stimulation (Mora et al. 1979).

There were no benefits of supplementation to child behaviour at any time point in the Jamaican study. In Bogota, supplemented children were less apathetic at age 4 months (Mora et al. 1979).

\section{Child Schooling}

All studies examined the effect of intervention on child schooling. In Jamaica, no significant benefits of stimulation were found to children's school achievement at age 11-12 years (Chang et al. 2002), but at age 17-18 years, adolescents who had received stimulation performed better on an educational reading test (Walker et al. 2005) and there was a trend towards stimulation reducing the likelihood of dropping out of school and of being suspended or expelled from school (Walker et al. 2006). There were no benefits of supplementation to school achievement or schooling trajectories at any time point. In Bogota, early stimulation led to a significant effect on reading readiness for boys only $3 \frac{1}{2}$ years after the end of the intervention while supplementation benefited children with mothers with more psychological resources (Super et al. 1991). 
In Cali, Colombia there was a dose response relationship between the lengths of time children had participated in the combined nutrition and stimulation intervention and their rates of school failure and grade level achieved (McKay \& McKay 1983).

\section{Child Nutritional Status}

In the Jamaica study, no benefit to child growth from stimulation was found at any age. Supplementation benefited child growth concurrently and younger children benefited most (Walker et al. 1991) but the effects were not sustained and no benefits of supplementation were found at age 7-8 years (Walker et al. 1996) or 11-12 years (Walker et al. 2000). In Bogota, Colombia, no benefits to child growth were found at age 3, but at age 6 stimulation benefited children's height for age (Super et al. 1990). The authors suggested that mothers receiving the home visiting intervention may have adopted better feeding practices resulting in improved nutritional status of the children.

In the Cali, Colombia study, height and weight gain increased in a dose response manner with the lengths of time children had been exposed to the combined stimulation and nutritional supplementation intervention (McKay et al. 1978), but these benefits to nutritional status were no longer evident at age 10 years (Perez-Escamilla \& Pollitt 1995).

\section{Child Health}

None of the studies examined the effect of intervention on child health.

\section{Maternal Outcomes}

\section{Parenting}

Two studies included measures of parenting. In Jamaica, no benefits of stimulation or supplementation were found to mothers' interaction with the child at home after six months of intervention (Meeks-Gardner et al. 1999). In Bogota, Colombia, mothers' receiving home visits were more attentive and responsive with their infants at 4 months than mothers in the comparison groups (Mora et al. 1979) while no benefits were found from supplementation alone.

\section{Maternal Psychosocial Function}

No studies investigated the effect of stimulation on maternal psychosocial function. 


\section{Maternal Life Course and Maternal-Child Interaction}

None of the studies included measures of maternal life course or mother-child interaction.

\section{Summary of Combined Nutrition and Stimulation Interventions}

The studies reviewed in this section indicate that early stimulation with or without nutritional supplementation benefits children's mental development over the short term and that these benefits are sustained over time. Although there is limited evidence of benefits to children's school achievement, benefits were found to children's schooling trajectories (e.g. school failure, grade level achieved and school suspensions and expulsions). There is insufficient evidence to draw any conclusions about the effects of combined nutrition and stimulation programmes on child behaviour although it was also encouraging that early stimulation for two years in early childhood produced significant benefits to mental health in adolescence (Walker et al. 2006). There is also insufficient evidence to make any conclusions regarding the effect of these interventions on maternal outcomes. Nutritional supplementation alone is insufficient to produce long term gains to children's development and behaviour or to mothers' parenting behavior in the short-term. 
Table 4: Combined Nutrition and Stimulation Interventions with Children and Their Families in Developing

Countries

\begin{tabular}{|c|c|c|c|c|}
\hline Country & Study Design & Intervention & Concurrent Effects & Long-term Effects \\
\hline $\begin{array}{l}\text { Jamaica } \\
\text { Chang et } \\
\text { al. 2002 } \\
\text { Grantham- } \\
\text { McGregor } \\
\text { et al, } \\
1991, \\
1997 \\
\text { Meeks- } \\
\text { Gardner et } \\
\text { al. 1995, } \\
1999 \\
\text { Walker et } \\
\text { al. } 1991 \text {, } \\
1996, \\
2000, \\
\text { 2005, } \\
\text { 2006 } \\
\text { Upper- } \\
\text { middle } \\
\text { income } \\
\text { country }\end{array}$ & $\begin{array}{l}129 \text { stunted } \\
\text { children age } \mathbf{9 - 2 4} \\
\text { months randomized } \\
\text { to } 4 \text { groups: } \\
\text { 1. supplementation } \\
\text { 2. stimulation } \\
\text { 3. supplement \& } \\
\text { stimulation } \\
\text { 4. placebo }\end{array}$ & $\begin{array}{l}\text { Duration: } 2 \text { years } \\
\text { Conducted by: } \\
\text { Paraprofessionals } \\
\text { Supplementation: } \\
1 \mathrm{~kg} \text { milk based } \\
\text { formula/week } \\
\text { giving } 750 \text { kcal, } \\
\text { 20g protein daily } \\
\text { Placebo: home } \\
\text { visits only } \\
\text { Stimulation: } \\
\text { Weekly home visits } \\
\text { Play activities were } \\
\text { demonstrated to the } \\
\text { mother and } \\
\text { parenting support } \\
\text { and advice was } \\
\text { provided. Home } \\
\text { made toys, books } \\
\text { and household } \\
\text { items were used for } \\
\text { the play activities. } \\
\text { Training or and } \\
\text { Paraprofessionals } \\
\text { received one week } \\
\text { of initial training } \\
\text { and ongoing } \\
\text { monitoring and } \\
\text { supervision was } \\
\text { provided. }\end{array}$ & 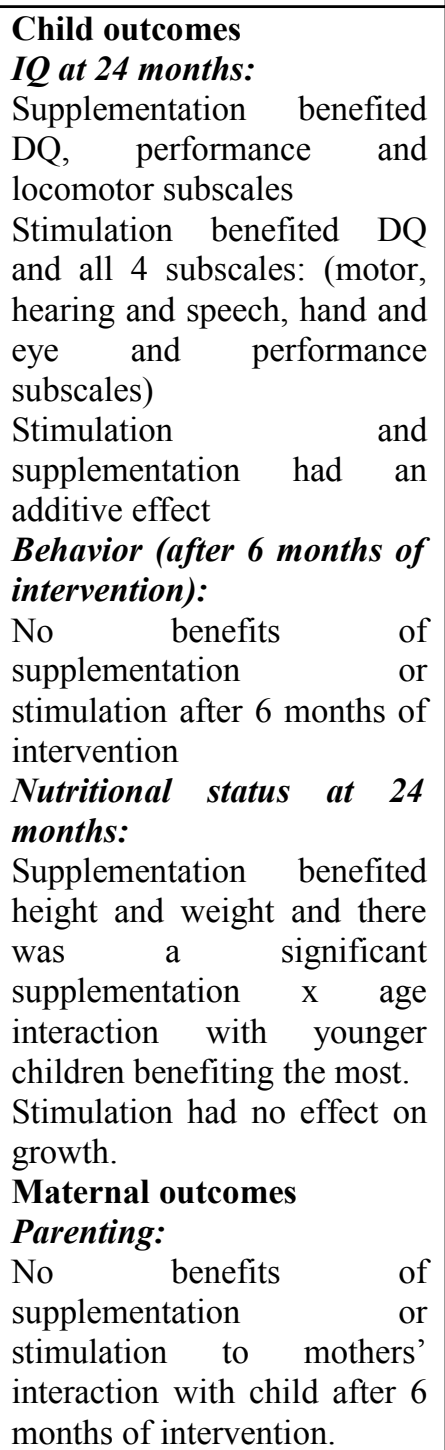 & $\begin{array}{l}\text { Child outcomes } \\
\text { At } 7-8 \text { years: } \\
\text { IQ } \\
\text { Supplementation and stimulation benefited significantly more tests than } \\
\text { would be expected by chance but no significant differences on any one test. } \\
\text { Stimulation also benefited perceptual motor function. } \\
\text { Nutritional status: } \\
\text { No benefits of supplementation or stimulation on growth were found. } \\
\text { At } 11-12 \text { years: } \\
\text { IQ: } \\
\text { No benefit from supplementation } \\
\text { Stimulation had benefits in reasoning (Raven's matrices), vocabulary and } \\
\text { IQ on the WISC-R and verbal but not performance subscale. } \\
\text { Schooling: } \\
\text { No significant benefits on school achievement. } \\
\text { Nutritional status: } \\
\text { No benefits of supplementation or stimulation on growth were found. } \\
\text { At } 17-18 \text { years: } \\
\text { No benefits from supplementation on any measures } \\
\text { IQ: } \\
\text { Significant benefits of stimulation on full scale IQ, PPVT, verbal analogies } \\
\text { test and reading tests (Effect sizes } 0.4 \text { to } 0.6 \text { ). } \\
\text { No significant benefits to working memory, mathematics and non-verbal } \\
\text { reasoning. } \\
\text { Schooling: } \\
\text { Participants who received stimulation had similar school drop out rates to } \\
\text { the non-stunted group whereas significantly more previously stunted who } \\
\text { did not receive stimulation dropped out of school. } \\
\text { Trend towards stimulated participants to be less likely to be suspended from } \\
\text { school or to be expelled. } \\
\text { Mental Health: } \\
\text { Significant benefits of stimulation to anxiety, depression, self-esteem and } \\
\text { attention deficit (Effect sizes } 0.4-0.49 \text { ). } \\
\text { Trend towards less oppositional behavior by parent report. } \\
\text { No significant benefits to antisocial behavior or hyperactivity. } \\
\text { al }\end{array}$ \\
\hline
\end{tabular}


Table 4 (continued): Combined Nutrition and Stimulation Interventions with Children and Their Families in Developing Countries

\begin{tabular}{|c|c|c|c|c|}
\hline Country & Study Design & Intervention & Concurrent Effects & Long-Term Effects \\
\hline $\begin{array}{l}\text { Bogotá, Colombia } \\
\text { Waber et al. 1981; } \\
\text { Super et al. 1990; } \\
\text { Super et al. 1991; } \\
\text { Mora et al. 1979, } 1981\end{array}$ & $\begin{array}{l}\text { High risk families randomized } \\
\text { to } 6 \text { groups: } \\
\text { A: control group } \\
\text { B. Supplement from } 6-36 \\
\text { months } \\
\text { C. Supplement from pregnancy } \\
\text { to } 6 \text { months } \\
\text { D. Supplement from pregnancy } \\
\text { to } 36 \text { months } \\
\text { E. Maternal education from } \\
\text { birth-36 months } \\
\text { F. Supplementation from } \\
\text { pregnancy to } 36 \text { months }+ \text { E } \\
\text { above. } \\
\text { Children aged from birth to } \\
\mathbf{3 6} \text { months }\end{array}$ & $\begin{array}{l}\text { Duration: } 3 \text { years } \\
\text { Conducted } \\
\text { Paraprofessional } \\
\text { Supplement } \\
856 \text { kcals/day } 38.4 \mathrm{~g} \text { protein }+ \\
\text { vitamins \& minerals } \\
3-6 \text { months } 125 \mathrm{~g} / \mathrm{wk} \text { of } \\
\text { skimmed milk }+ \text { vegetable and } \\
\text { protein mixture } \\
6-12 \text { months } 1 \text { lb whole dry } \\
\text { milk } 250 \mathrm{~g} \text { of high protein } \\
\text { vegetable mix }+ \text { iron } \\
>12 \text { mths } 623 \text { kcals }+20 \mathrm{~g} \\
\text { protein/day }+ \text { vitamins } \& \\
\text { minerals } \\
\text { Stimulation involved training } \\
\text { mothers during home visits. } \\
\text { Home visitors worked directly } \\
\text { with children and promoted } \\
\text { positive mother-child } \\
\text { interactions. } \\
\text { available in the homes were } \\
\text { used to foster child } \\
\text { exploration. } \\
\text { Training } \\
\text { Not specified aterials }\end{array}$ & $\begin{array}{l}\text { Child outcomes } \\
\text { IQ: } \\
\text { Supplement benefited all of the } \\
\text { Griffith's subscales and total } \\
\text { DQ. } \\
\text { Stimulation benefited hearing } \\
\text { and speech subscale only at } 36 \\
\text { months } \\
\text { Child behavior: } \\
\text { At } 4 \text { months, supplemented } \\
\text { children less apathetic. } \\
\text { Infants receiving stimulation } \\
\text { cried less } \\
\text { Nutritional status: } \\
\text { No effect of stimulation on } \\
\text { growth at age } 3 \\
\text { Maternal outcomes } \\
\text { Parenting: } \\
\text { No benefits of supplementation } \\
\text { to maternal behavior. } \\
\text { Mothers in education group } \\
\text { more attentive and responsive } \\
\text { at } 4 \text { months }\end{array}$ & $\begin{array}{l}\text { Child outcomes } \\
\text { Schooling: } \\
31 / 2 \text { years after intervention, } \\
\text { supplementation benefited } \\
\text { scores on reading readiness } \\
\text { primarily for children with } \\
\text { mothers with more } \\
\text { psychological resources. } \\
\text { No benefit on arithmetic or } \\
\text { knowledge } \\
31 / 2 \text { years after intervention, } \\
\text { stimulation had a marginally } \\
\text { significant effect on reading } \\
\text { readiness for boys only. } \\
\text { Nutritional status: } \\
\text { Stimulation benefited height } \\
\text { for age at age } 6 \text {. }\end{array}$ \\
\hline
\end{tabular}


Table 4 (continued): Combined Nutrition and Stimulation Interventions with Children and Their Families in Developing Countries

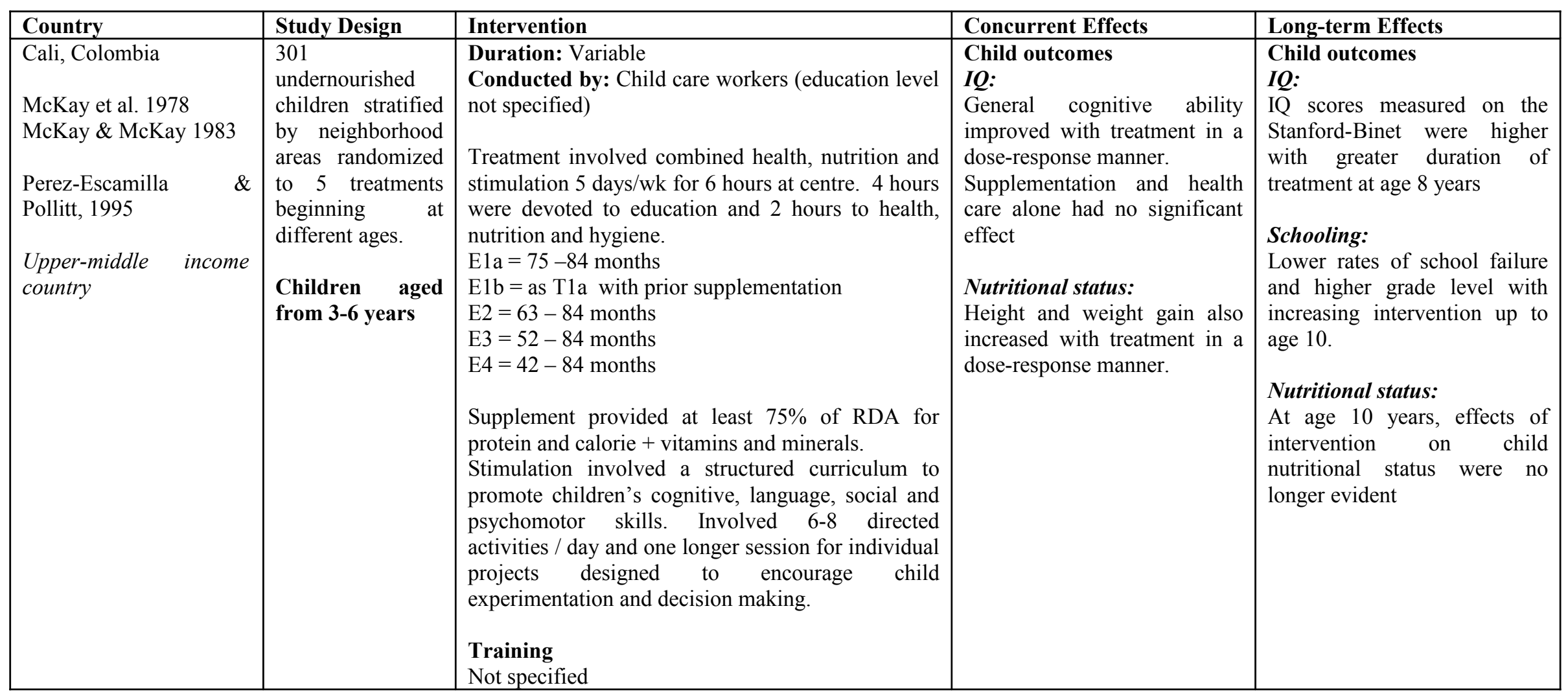




\section{Stimulation Interventions for Children At-Risk due to Health Problems}

Three studies that examined the effect of a stimulation intervention for children at-risk due to health problems were identified and all utilized a randomized design. One study was conducted in an upper-middle income country and two in lower middle income countries. Two studies intervened with children from birth, one study from China with preterm infants (Bao et al. 1999) and one study from India with infants discharged from a special care neonatal nursery (Nair et al. 2009). The third study involved early stimulation for children infected with HIV (Potterton et al. 2010). In two studies the intervention was primarily delivered by professionals in a hospital clinic setting (Nair et al. 2009, Potterton et al. 2010) and the caregivers were asked to conduct stimulation activities at home. In two studies, the intervention was conducted over 1 year (Nair et al. 2009, Potterton et al. 2010), and in one over 2 years (Bao et al. 1999). The studies are described in detail in Table 5.

\section{Child Outcomes}

\section{Child Mental and Motor Development}

All three studies measured children's mental and motor development and all found benefits to mental development and two reported benefits to motor development (Nair et al. 2009, Potterton et al. 2010). The study by Bao and colleagues found no benefits to the motor development of children born preterm after an intervention lasting two years. In the study with infants discharged from a special care nursery, some benefits of intervention were sustained at one year follow-up (Nair et al. 2009). In the study with children infected with HIV, although significant benefits of intervention were found, the children in the intervention group continued to be severely developmentally delayed (Potterton et al. 2010).

\section{Child Nutritional Status}

Two studies included measures of child nutritional status (Nair et al. 2009, Potterton et al. 2010). In the study with children discharged from a special care nursery significant benefits were found to child weight and height after one year of intervention and significant benefits to child length were found at the one year follow-up (Nair et al. 2009). No significant benefits of stimulation to children's nutritional status were found in the South African study with HIV-infected children (Potterton et al. 2010). 


\section{Child Behavior, Schooling and Health}

None of the studies examined the effect of intervention on child behavior schooling or health.

\section{Maternal Outcomes}

None of the studies included measures of maternal outcomes.

\section{Summary of Stimulation Interventions for Children At-Risk Due to Health Problems}

These studies show that early stimulation with children at-risk due to health problems in developing countries benefits children's mental development over the short term. There is some evidence that children's motor development also benefits although this was only found in two of the three studies. In one study, early stimulation with at-risk neonates for the $1^{\text {st }}$ year of life also benefited children's nutritional status. There is no evidence on the effect of these interventions on child behavior, schooling or health or on maternal outcomes. 
Table 5: Stimulation Interventions with Children at Risk Due to Health Problems in Developing Countries

\begin{tabular}{|c|c|c|c|}
\hline Study & Sample & Intervention & Short term effects \\
\hline $\begin{array}{l}\text { China } \\
\text { Bao et al. } \\
1999 \\
\text { Lower-middle } \\
\text { income } \\
\text { country }\end{array}$ & $\begin{array}{l}103 \text { preterm infants }(28-36.9 \\
\text { weeks gestation) randomly } \\
\text { assigned to intervention } \\
(\mathrm{n}=52) \text { or a conventional } \\
\text { care condition }(51) \text {. }\end{array}$ & $\begin{array}{l}\text { Duration: } 2 \text { years } \\
\text { Conducted by: paraprofessionals } \\
\text { Mothers were trained to conduct activities to } \\
\text { promote children's motor, cognitive and } \\
\text { speech development and their social } \\
\text { behavior. Educational toys were also } \\
\text { provided. }\end{array}$ & $\begin{array}{l}\text { Child outcomes } \\
\text { Mental and motor development: } \\
\text { Significant benefits of intervention to children's mental } \\
\text { development index at age } 18 \text { and } 24 \text { months. } \\
\text { No significant benefits of intervention to children's motor } \\
\text { development. }\end{array}$ \\
\hline $\begin{array}{l}\text { South India } \\
\text { Nair et al. } \\
2009 \\
\text { Lower-middle } \\
\text { income } \\
\text { country }\end{array}$ & $\begin{array}{l}800 \text { babies discharged from } \\
\text { special care neonatal nursery } \\
\text { randomized to an } \\
\text { Intervention group }(n=400) \\
\text { or control group }(n=400) \\
83 \% \text { followed up at end of } \\
\text { intervention } \\
92 \% \text { followed up one year } \\
\text { after the end of the } \\
\text { intervention }\end{array}$ & $\begin{array}{l}\text { Duration: } 1 \text { year } \\
\text { Conducted by: Professionals (occupational } \\
\text { therapists) } \\
\text { Intervention involved training mothers } \\
\text { individually and in groups in early } \\
\text { stimulation in the hospital. It is unclear how } \\
\text { many training sessions the mothers attended. } \\
\text { Monthly follow-up visits at home were used } \\
\text { to monitor compliance although it is not } \\
\text { clear whether mothers were also provided } \\
\text { with assistance in implementing the } \\
\text { intervention during these visits. } \\
\text { Training } \\
\text { Not specified }\end{array}$ & $\begin{array}{l}\text { Child outcomes: } \\
\text { Mental and motor development: } \\
\text { Significant benefits after } 1 \text { year of intervention to mental } \\
\text { development (effect size }=0.38 \text { ) and motor development (effect } \\
\text { size }=0.40 \text { ) on the Bayley Scales of Infant Development. } \\
\text { At one year follow up, significant benefits of intervention were } \\
\text { found for children's mental development (effect size }=0.21 \text { ) and } \\
\text { motor development (effect size }=0.25 \text { ). } \\
\text { Nutritional status: } \\
\text { Significant benefits to child weight (effect size }=0.2 \text { ) and length } \\
\text { (effect size }=0.21 \text { ) after } 1 \text { year of intervention and no significant } \\
\text { benefits to head circumference. } \\
\text { At one year follow up, significant benefits were found for child } \\
\text { length (effect size }=0.21 \text { ). No significant benefits to child weight or } \\
\text { head circumference. }\end{array}$ \\
\hline
\end{tabular}


Table 5 (continued): Stimulation Interventions with Children at Risk Due to Health Problems in Developing Countries

\begin{tabular}{|c|c|c|c|}
\hline Study & Sample & Intervention & Short term effects \\
\hline $\begin{array}{l}\text { Soweto, South } \\
\text { Africa } \\
\text { Potterton et } \\
\text { al. } 2010 \\
\text { Upper-middle } \\
\text { income } \\
\text { country }\end{array}$ & $\begin{array}{l}122 \text { HIV positive children } \\
\text { aged less than } 2 \frac{1}{2} \text { years } \\
\text { randomized to an } \\
\text { intervention group }(n=60) \\
\text { or control group }(n=62) \\
43 / 60 \text { intervention followed } \\
\text { up }(72 \%) \\
49 / 62 \text { control children } \\
\text { followed up }(79 \%)\end{array}$ & $\begin{array}{l}\text { Duration: } 1 \text { year } \\
\text { Conducted by: Professionals } \\
\text { (physiotherapist) } \\
\text { Intervention involved provision of a basic } \\
\text { home stimulation program which was } \\
\text { individualized for each child and was based } \\
\text { on the concerns and priorities of the } \\
\text { caregiver and the results of a developmental } \\
\text { test. The program was structured around } \\
\text { activities of daily living and other activities } \\
\text { that could be incorporated into the family's } \\
\text { daily routine. } \\
\text { Caregivers were advised in the use of this } \\
\text { program during } 3 \text { monthly clinic visits. } \\
\text { Training } \\
\text { Not specified }\end{array}$ & $\begin{array}{l}\text { Child Outcomes } \\
\text { Mental and motor development: } \\
\text { Significant benefits of intervention to mental and motor } \\
\text { development on the Bayley Scales of Infant Development. } \\
\text { Nutritional status: } \\
\text { No significant benefits of intervention to child height for age, } \\
\text { weight for age, weight for height or head circumference. }\end{array}$ \\
\hline
\end{tabular}




\section{Overall Summary of the Benefits of Early Stimulation Interventions}

Taken as a whole, the studies reviewed indicate that early stimulation interventions for young children produce significant benefits to children's mental development (20/21 studies found benefits) and there is some evidence that children's motor development also benefits (7/12 studies found benefits). There is also reasonable strong evidence for benefits to children's behaviour ( $9 / 10$ studies found benefits) and some evidence of benefits to children's schooling, especially children's schooling trajectories ( $4 / 5$ studies found benefits). The studies reviewed indicate that early stimulation interventions do not generally lead to benefits to children's nutritional status (only 4/13 studies found benefits) and none of the studies included child health outcomes.

In terms of maternal outcomes, there is also reasonably strong evidence that mothers' parenting knowledge and skills can improve with early stimulation interventions (14/16 studies found benefits). The evidence as to whether there are benefits to maternal psychosocial function is inconsistent (only $2 / 5$ studies found benefits) and may depend on the amount and type of support provided for the mother through the intervention. There is insufficient evidence as to whether early stimulation interventions can benefit maternal life course (only one study included any measures of this and benefits were found for mothers' status in the family).

Only seven studies had a longer-term follow-up and all seven reported sustained benefits. Benefits were found for a broad array of outcomes including maternal reports of child behaviour (Klein \& Rye 2004, Walker et al. 2010), child cognition (Kagitcibasi et al. 2001, GranthamMcGregor et al. 1994, 1997, Walker et al. 2000, 2005, Walker et al. 2010, McKay et al. 1978), children's academic achievement (Kagitcibasi et al. 2001, Super et al. 1991, Walker et al. 2005), child schooling trajectories (McKay \& McKay 1983, Walker et al. 2006) and participants' mental health in adolescence (Walker et al. 2006).

The studies reviewed thus show that stimulation interventions with young children and their families can have significant benefits to children's development and to parenting behaviors when implemented in a range of different cultural and economic contexts and when delivered by paraprofessional or professional staff. However, the studies reviewed were all efficacy studies involving relatively small sample sizes and for the most part conducted under the close supervision of research staff. In many studies, extensive training and supervision was provided 
for the persons delivering the intervention to ensure high quality and fidelity of intervention delivery. When such programs are taken to scale, implementation issues (for example, lower levels of monitoring and supervision, higher staff turn-over, lower availability of resources) may lead to an attenuation of the benefits to child and maternal outcomes. However, there is some evidence from large scale evaluations of early child development programs in developing countries that significant benefits to child development are possible. Two such evaluations are described in table 6 overleaf. For example, an integrated child health, nutrition and development intervention for children aged birth to four years in the Philippines showed benefits to children's mental and motor development, social and emotional skills, and child nutritional status with average effect sizes across all outcomes of $0.45 \mathrm{SD}$. Benefits to children's mental development (including cognition and receptive and expressive language) averaged 1.02SD which is larger than found in most efficacy trials. Other examples of large scale programs promoting child development are included in the following sections if they included analyses on the differential effectiveness of interventions, if they investigated what program characteristics affect the success of interventions or if they included information on cost effectiveness. 
Table 6: Examples of large scale programme evaluations of stimulation interventions in developing countries

\begin{tabular}{|c|c|c|c|}
\hline Study & Sample & Intervention & Short term effects \\
\hline $\begin{array}{l}\text { Philippines } \\
\text { Armecin et } \\
\text { al. } 2006\end{array}$ & $\begin{array}{l}6693 \text { children aged 0- } \\
4 \text { years on enrollment } \\
4,140 \text { from program } \\
\text { areas } \\
2,359 \text { from non- } \\
\text { program areas }\end{array}$ & $\begin{array}{l}\text { Comprehensive early child development } \\
\text { program integrated using a multi-sectoral } \\
\text { approach. Included focus on child heath, } \\
\text { nutrition and development. } \\
\text { Services included centre based services (e.g. } \\
\text { day care centers, preschools, health stations) } \\
\text { and home-based services (e.g. family day } \\
\text { care programs, home visits). }\end{array}$ & $\begin{array}{l}\text { Child Outcomes } \\
\text { IQ: } \\
\text { Significant benefits from intervention for cognitive skills (effect } \\
\text { size }=0.55 \text { ), expressive language (effect size }=1.09 \text { ), receptive language } \\
\text { (effect size }=1.43 \text { ), gross motor skills (effect size }=0.79 \text { ), self-help skills } \\
\text { (effect size }=0.33 \text { ) and fine motor skills (effect size }=0.65 \text { ). } \\
\text { Program impacts increase with duration. } \\
\text { Benefits most pronounced for children below age four at time of final } \\
\text { survey (age } 2-3 \text { at enrollment) and for children who had been exposed } \\
\text { to the program for }>17 \text { months. } \\
\text { Behavior: } \\
\text { Significant benefits to social-emotional skills (effect size } 0.55 \text { ). } \\
\text { Nutrition: } \\
\text { Significant benefits from intervention for weight for height (effect } \\
\text { size=0.23) and proportion wasted (effect size }=0.01 \text { ). } \\
\text { No significant benefits on proportion stunted and height for age } \\
\text { Significant differences favoring non-program areas were found for } \\
\text { proportion anemic and hemoglobin count. } \\
\text { Health: } \\
\text { No significant benefits on percentage with worms or diarrhea. }\end{array}$ \\
\hline $\begin{array}{l}\text { Bolivia } \\
\text { Behrman et } \\
\text { al. } 2003\end{array}$ & $\begin{array}{l}1198 \text { children aged 6- } \\
72 \text { months from poor, } \\
\text { urban areas. }\end{array}$ & $\begin{array}{l}\text { PIDI program (Proyecto Integral de } \\
\text { Desarrollo Infantil). } \\
\text { Day care, nutrition and educational services } \\
\text { to children. } \\
\text { Child attend full time day care in groups of } \\
\text { up to } 15 \text { children (staff:child ratio }=1: 5 \text { ). } \\
70 \% \text { of children's nutritional needs are } \\
\text { supplied through the day care service. } \\
\text { Also involves health and nutrition monitoring } \\
\text { and educational activity programming. }\end{array}$ & $\begin{array}{l}\text { Child outcomes } \\
\text { Measured gross and fine motor skills, language-auditory skills, psycho- } \\
\text { social skills. } \\
\text { Positive effects are found for children who participated for at least } 7 \\
\text { months and the effects are stronger with longer duration. } \\
\text { Estimated cost-benefit ratios to range from } 1.7 \text { to } 3.7 \text {. }\end{array}$ \\
\hline
\end{tabular}




\section{Who Benefits Most From Early Interventions}

Studies were also reviewed for evidence as to whether early stimulation interventions benefit certain subgroups of children and/or families more than others. A discussion of who benefits most from stimulation interventions is discussed below.

\section{Child IQ}

The evidence for whether child IQ moderates the effect of intervention is conflicting. In Brazil, children with a mental development score of 100 or less on the Bayley Scales of Infant Development benefited more than children with a mental development score above 100 (Eickmann et al. 2003). In Peru, it was reported that of the children participating in the Project PRONEI (which involves educational day care including nutrition for 3-5 year old children), the children with lower developmental levels at pretest benefited more (WHO, 1999) However, in Turkey, children in the lowest quartile for IQ on enrollment did not benefit from early stimulation in the form of an educational centre-based intervention or mother training (Kagitcibasi et al. 2009).

\section{Child Gender}

Benefits have been reported to be specific for boys and girls and it is often the gender most disadvantaged in that population on the outcome in question that benefit. For example, in the evaluation of the Integrated Child Development Service (ICDS) in India (Chaturvedi et al. 1987), it was found that the positive effect of the intervention on school enrolment was for girls only as most of the boys in the control group were enrolled in school. Similarly, the ICDS was found to benefit non-verbal reasoning in girls only (WHO, 1999).

In Bogota, boys benefited more from early stimulation on a reading readiness test $3 \frac{1}{2}$ years after the end of the intervention (Super et al. 1990). In a study in Bangladesh a rather puzzling result was found - boys in intervention villages performed better on a vocabulary test than boys from control villages but girls performed worse (Aboud 2007). However, the study was quasi-experimental rather than randomized and there were no pretest scores so it is difficult to interpret the results. 


\section{Family Background}

Myers (1992) reviewed the effect of early childhood education on schooling in developing countries and reported that the greatest differences between children in intervention and control group were found for the most disadvantaged. For example, in a study in fourteen rural villages in India, school dropout by grade 3 was much greater for children who had not participated in the Integrated Child Development Services (ICDS) in the lower and middle castes than for children in the lower and middle castes who had attended the ICDS. However, no difference was found among children in the higher castes (Figure 3 ).

\section{Figure 3. School drop out for children with and without experience in ICDS according to caste}

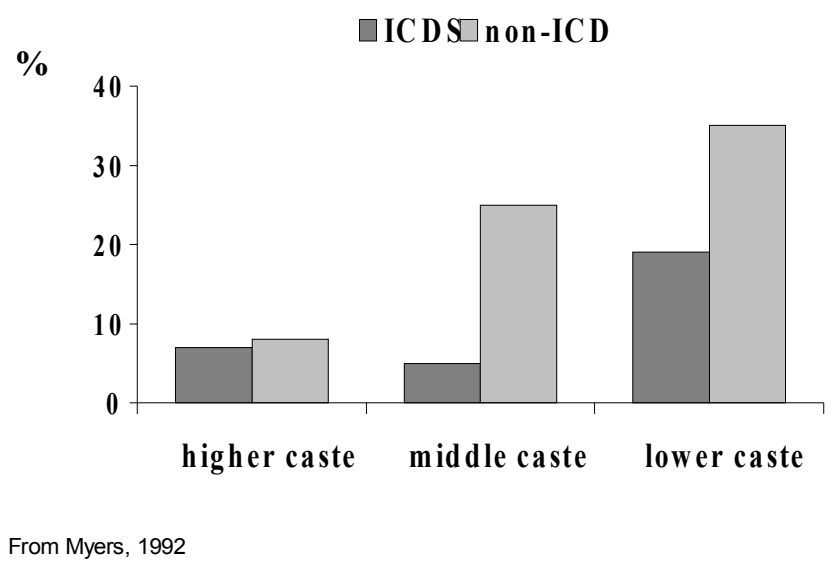

In Myanmar the early childhood care and development program involves a parenting component for families of children aged from birth to five years and a centre-based component for three to five year old children. An evaluation of this program by Save the Children (2004) showed that the program increased the chance of school enrollment for all children but that the gains were greatest for children from the poorest quartile (Figure 4). 
Figure 4. School enrollment rates for children with and without early childhood education experience in Myanmar by socio-economic status

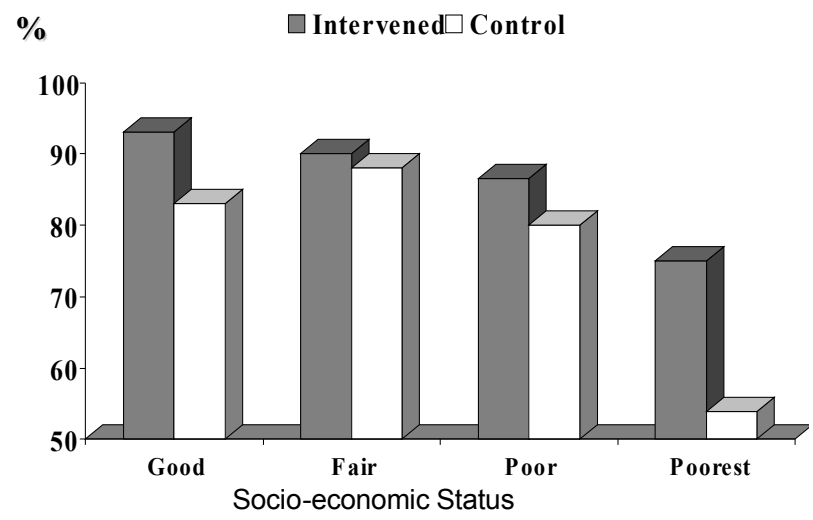

The benefit of stimulation to the most disadvantaged is analogous to findings from studies of nutritional supplementation. For example, in a Guatemalan study comparing the effect of a high calorie and protein supplement to a low calorie supplement, children from low SES families benefited the most in terms of cognition at age 4-5 years and on school achievement in adolescence (Pollitt et al. 1993) (Figure 5).

Figure 5. Long term effect of high calorie and protein supplement on vocabulary by SES in Guatemala

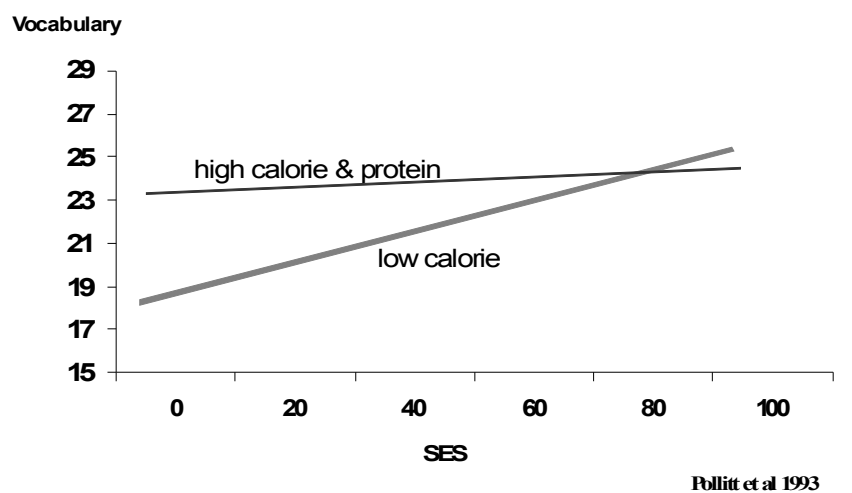

For maternal outcomes a different result is often found. In Bangladesh, mothers with more assets and with higher levels of education benefited more from an intervention involving weekly group workshops in terms of the level of stimulation provided in the home (Aboud 2007). The intervention was discussion based and did not involve a significant amount of role-play and 
practice activities and hence it is perhaps not surprising that more advantaged mothers were more able to understand and apply the strategies than less advantaged mothers. This finding that more educated mothers benefit more from stimulation interventions has however also been found in a study with disabled children in Vietnam (Shin et al. 2009) and in a study describing the effect of a nutrition education program in Peru (Robert et al. 2006). Educated mothers have been shown to have better recall of intervention messages (Robert et al. 2006) and have also been found to be more compliant (De Souza et al. 2006).

Similarly, there is some evidence that children of mothers with higher IQ benefit most from nutritional supplementation during the first few years of life. For example, among stunted children receiving supplementation in early childhood, only those children of mothers with higher IQ showed benefit on tests of perceptual-motor function at age 7-8 years (GranthamMcGregor et al, 1997). Similarly, in Bogota, among children with mothers with more psychological resources, those receiving supplementation benefited more in tests of reading readiness $3 \frac{1}{2}$ years after the end of the intervention period (Super et al. 1991).

\section{Child Biomedical or Nutritional Status}

All of the interventions with undernourished and term low birth weight children, the interventions described with preterm infants (Bao et al. 1999) and infants discharged from a special care neonatal nursery (Nair et al. 2009) and the intervention with HIV infected children (Potterton et al. 2010) showed benefits to child development indicating that children with compromised nutritional and/or biomedical status can benefit from appropriate early interventions. There is some evidence that children who are biologically vulnerable benefit more from early stimulation. For example, in Vietnam, stunted children benefited more on the Raven's Progressive Matrices IQ test from a two year intervention that involved strengthening early childhood education in their commune than their non-stunted counterparts (Watanabe et al. 2005).

\section{Maternal Psychosocial Function}

There is limited evidence from developing countries as to whether maternal psychosocial function moderates the effect of intervention. In Jamaica, there was no evidence that maternal depressive symptoms affected the outcome of the intervention and children of mothers with varying levels of depressive symptoms benefited from the intervention (Baker-Henningham et al. 2005). In South Africa, maternal depression at 6 and 12 months was not correlated with 
concurrent maternal sensitivity and responsiveness or with infant attachment at 18 months (Cooper et al. 2009).

\section{Summary of Who Benefits Most From Early Stimulation Interventions}

The evidence suggests that early childhood stimulation interventions generally benefit those children who are most vulnerable. The review of non-US early childhood interventions by Nores \& Barnett (2010) also concluded that there was some evidence that more disadvantaged children benefited more from the interventions (which included cash transfer, nutritional, educational and mixed interventions) than more advantaged children, particularly for schooling and nutritional outcomes. This is also consistent with evidence from the US (Barnett \& Belfield 2006). However, contrary results are found for maternal education and there is some evidence that mothers with higher levels of education benefit more from early stimulation interventions and that they understand the material better, are more able to implement the strategies they learn and are more compliant. Less educated mothers may need more intensive interventions and/or interventions that involve more demonstration, practice activities and role-plays to ensure they are able to translate the messages into concrete action.

\section{Program Characteristics Affecting Success}

The literature was also reviewed to identify program characteristics that impact on the effectiveness of early stimulation interventions on child and maternal outcomes.

\section{Intensity}

The intensity of the intervention has been found in several studies to affect the success of the intervention. A study in Jamaica investigated the effectiveness of differing intensities of a home visiting intervention (Powell \& Grantham-McGregor 1989). The intervention involved home visits for 2 years by paraprofessionals in which home made toys and books were brought to the home and the caregivers shown age appropriate activities to do with their child. Children receiving weekly visits were compared with those receiving fortnightly and monthly visits and a non-visited control group. The gains in child development were found to increase with increased frequency of visiting (Figure 6). 


\section{Figure 6. Effects of different visiting frequency on child DQ in Jamaica}

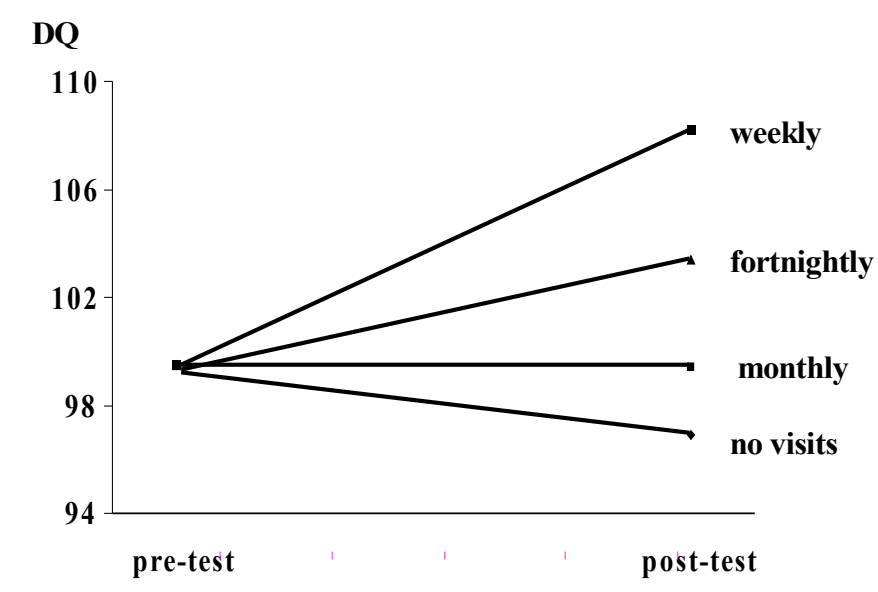

Powell \& Grantham-McGregor, 1989

In Bangladesh, a stimulation intervention for undernourished children that involved group meetings and home visits led to no significant benefits to motor development; however, benefits were greater for children who received more visits (Hamadani et al. 2006).

A similar trend has been reported for maternal outcomes - a home visiting intervention in Jamaica over 1 year led to significant benefits to maternal depressive symptoms. Mothers who received forty or more visits during the year benefited more than mothers receiving 25-39 visits; no benefits were found for mother receiving less than 25 visits (Baker-Henningham et al. 2005).

\section{Quality}

We would expect that the quality of the program would be an important factor influencing outcomes and yet few projects have examined this issue. The majority of studies reviewed for this report invested significant resources in staff training and staff were provided with initial training in the intervention, followed by ongoing supervision and monitoring. In addition, an intervention manual was usually available which documented the intervention in detail. Under these conditions, the majority of programs were found to be effective. When programs go to scale, the degree of training, monitoring and supervision often decreases and maintaining fidelity of implementation of the intervention becomes more challenging.

In Colombia, 'Homes of Well-Being' are supported in which community mothers (paraprofessionals) look after up to 15 children aged 2 to 5 years. Children are fed, their growth is monitored and educational activities are conducted. However, an evaluation of the program 
reported that in the majority of day care homes the food was not prepared adequately, the houses were often in poor condition and in over $25 \%$ of the homes, the community mothers did not plan any pedagogical activities (WHO, 1999). In a multi-variate analysis examining the effect of quality on children's development no relationship was found between duration of time in the program and the risk status of the children. There was however a small, but significant association $(\mathrm{r}=.17)$ between program quality and child well-being in terms of nutrition, health and psychosocial development. In addition, the proportion of children with a developmental delay was lower in homes run by the more experienced community mothers. These results suggest that the quality of the program was more important in predicting child development than the quantity of exposure the child received. In optimal conditions, both quality and quantity are likely to be related to child outcomes.

\section{Timing}

There is limited evidence from the literature as to the optimum time to begin an intervention for young children and their families. Timing is usually confounded with duration. Ramey and Ramey (1998) summarize evidence from the global early education literature and conclude that programs which begin earliest and continue longest produce the greatest effects although they cite only child-focused, centre-based services to support their view. In the Philippines (Armecin et al. 2006), a large scale evaluation of the early childhood program showed that children benefited more if they had been enrolled in the program at age two to three years compared to children enrolled at a later age. Younger children were also found to benefit more in an evaluation of the Roving Caregivers' home visiting program in St. Lucia - the cognitive development of children aged 6-18 months at program start was enhanced by the program whereas no benefits were found for the cognitive development of children aged 18-30 months at program start (Caribbean Child Support Initiative 2008). Evidence for optimal timing for early stimulation is also available from studies involving children in severely deprived environments such as institutions and these studies find that that the younger the child is when they are removed from these environments into appropriate foster care, the better the outcome - with partial evidence that children in the first two years of life do better than children fostered later (Nelson et al. 2007). There is also some evidence that first two years of life is most sensitive to the effects of undernutrition (Grantham-McGregor \& Baker-Henningham 2005). In a recent review of early childhood interventions, which included cash transfer, nutritional, educational 
and mixed interventions, Nores \& Barnett (2010) reported that programs that target infants and toddlers alone and pre-K children alone produced larger benefits than programs that targeted both ages at the same time. This may reflect differences in the characteristics of the program rather than the age of the children as interventions that target a specific age range are likely to be more focused than those that target children over a wider age range.

\section{Duration}

The duration of the intervention has also been shown to be related to child outcomes. In the study in Cali, Colombia, treatment involved from one to four 9 month interventions of a combined health, nutrition and stimulation intervention at a day care centre and one group which received health and nutrition only, prior to one 9 month combined intervention. At age 7 years, the combined intervention improved general cognitive ability in proportion to the number of treatment periods received (Figure 7). Children receiving treatment also performed better than a group of adequately nourished children from the same neighborhoods but performed worse than children from high SES backgrounds. At follow up, one and two years after the end of the intervention, the IQ of the children was also directly related to the duration of intervention (McKay et al. 1978). Height and weight gain were also directly related to the duration of the intervention throughout the study period (Perez-Escamilla \& Pollitt 1995).

Figure 7. Dose -response effect on child cognition of a combined health, nutrition and stimulation intervention in Cali, Colombia

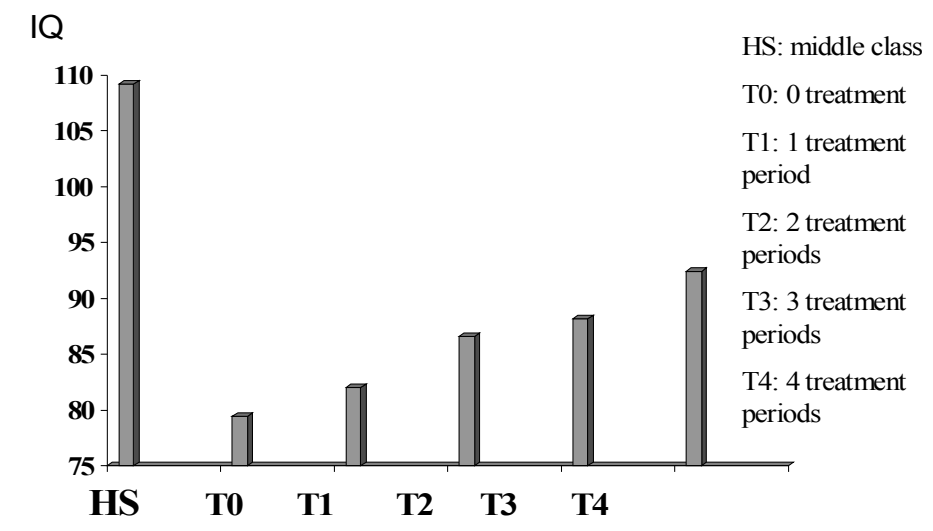

McKay et al, 1978 
Large scale evaluations have also shown the importance of sufficent duration. In the Phillipines, children who had been exposed to the early childhood program for more than seventeen months benefited more in terms of IQ scores and in Bolivia, positive effects on child development of an educational day care program for 6-72 month old children from poor urban areas were only found for children who had participated for at least seven months and the effects were stronger with longer duration (Behrman et al. 2003). The review of non-US early childhood interventions by Nores \& Barnett (2010) also found partial evidence to suggest that interventions that lasted over 1 year produced greater benefits than interventions lasting less than one year.

\section{Personnel Delivering the Intervention}

The majority of studies reviewed for this report involved interventions that were conducted by paraprofessionals (16/22 of the studies that reported the qualifications of the personel). It is encouraging that interventions conducted by paraprofessionals produced these widespread benefits to children and mothers in developing countries as the cost of using professionals would be prohibitive in many countries. This is contrary to results from the US which indicate that home-visiting interventions conducted by paraprofessionals are largely ineffective and that professionals are required for optimal outcomes (Olds \& Kitzman 1993). It should be noted however, that training and supervision of staff is likely to be key to successful interventions and as mentioned previously, the majority of studies paid close attention to these aspects of the intervention.

\section{Mode of Delivery}

Early stimulation interventions can be delivered through a variety of modalities including homevisiting, group parent meetings, educational day care provision, child development messages integrated into routine health care visits and/or through media interventions. For this report, no study was identified that investigated the effectiveness of different modes of delivery and the majority of studies used a home-visiting approach which was supplemented with parent group meetings in some studies. No peer reviewed journal articles describing the impact of educational day care provision for children aged from birth to three were identified although there are several large scale programs that have used this approach (e.g. PRONEI in Peru described in WHO, 1999). It is likely that the most effective and appropriate delivery mode will vary across cultures and across contexts. For example, group sessions in nutrition centres with mothers of 
undernourished children was a feasible strategy in rural Bangladesh (Hamadani et al. 2006), but was not appropriate in urban Jamaica where community violence, inadequate transportation and strict clinic dress codes were some of the factors that led to poor attendance (Baker 2003). Similarly, improving the quality of day care may be particularly important in areas where a high proportion of children attend day care facilities but centre-based services would be less appropriate in populations where the majority of young children are cared for at home.

\section{Focus of Intervention}

Early stimulation interventions can be child-focused (e.g. educational day care), parent-focused (parent group meetings) or joint focused (intervention intervenes directly with the child and the parent). The majority of the interventions reviewed for this report involved a home visiting component (18/26 studies) and seven of those eighteen studies also conducted group parenting sessions. In addition, two studies combined centre-based services with a parent training component (Watanabe et al. 2005, Kagitcibasi et al. 2001, 2009). In all of these studies there was a joint focus on both the parent and the child, with educational activities involving home-made toys and books for the child and parenting support for the mother. Hence the interventions focussed not only on the young child's development but also on the well-being of the mother and the family. This joint focus is likely to be an important factor in explaining the success of the programmes. Evidence from studies in the US suggests that home visiting interventions are less

effective than centre based services for promoting child outcomes (Ramey \& Ramey 1998) but many of the US home-visiting programmes were mainly parent focused and did not have a strong child-focused component.

\section{Methods Used in Intervention}

There is some evidence from the studies reviewed that active involvement of the mother in the intervention leads to better outcomes. It is recommended that the intervention actively involves the mother in conducting the stimulation activities with appropriate feedback and that the mother is encouraged to continue the activities on a daily basis. Interventions using discussion and information sharing only have been shown to be less effective (Aboud 2007) and hands-on practical activities are recommended. In addition, the majority of the interventions used low cost materials (for example, home-made toys, books and pictures and/or items in the home) to 
promote child play, rather than using store-bought toys and books which would be cost prohibitive in most developing countries.

\section{Summary of Programme Characteristics Affecting Success}

The available evidence suggests that programs of high quality programs delivered with higher intensity and over a longer duration are most effective. There is limited evidence about the most appropriate mode of delivery and this may vary across context. Stimulation interventions have been shown to be more effective if started at a younger age although there is no evidence as to whether interventions starting at birth or in the first few months of life are more or less effective than interventions that start in later infancy. Interventions can be delivered effectively by paraprofessionals with appropriate supervision and there is some suggestion that they are more effective if they target both the mother and the child. Active involvement of the mother in the intervention is important and information sharing and discussion based interventions are likely to be ineffective, especially with mothers living in disadvantaged circumstances and mothers with low levels of education.

\section{By What Mechanisms Do Early Stimulation Interventions Have Their Effects}

Few studies have examined the mechanism through which stimulation interventions have their effects. Several mechanisms are possible. Firstly, stimulation during the first three years of life help to prevent changes to brain structure and neurological pathways associated with the stressful influences faced by children living in disdavantaged circumstances (Shonkoff et al. 2009). Secondly, early stimulation programmes have been shown to benefit mothers' parenting behaviour, mother-child interaction and the level of stimulation provided in the home and stimulation in the home has been shown to be an independent predictor of children's mental development in developing countries in several studies (Hamadani et al. 2010, Santos et al. 2008) particulary for children who are more vulnerable or disadvantaged (Barros et al. 2009, GranthamMcGregor et al. 1998). One study, a home visiting intervention with term low birth weight children in Jamaica, did demonstrate that the benefits to child development were partially mediated by the levels of stimulation in the home (Walker et al. 2004). Early stimulation programmes has also been shown to lead to benefits to maternal mental health which is a risk factor for poor child development (Wachs et al. 2009). However, two studies have examined 
whether changes in maternal depression were associated with change in child development (Baker-Henningham et al. 2005) or child attachment (Cooper et al. 2009) and in neither study was the effect of intervention mediated by the reduction in maternal depressive symptoms. Early stimulation may also benefit children by enhancing their ability to benefit from other educational opportunities, for example, by boosting their school readiness skills so that they are more able to benefit from school.

\section{The Cost of Early Childhood Education Programs}

The cost of early childhood care and development programs is obviously an important consideration for resource poor countries. A cost-benefit analysis of the Perry Preschool Program in the US estimated that for every dollar invested in the program, $\$ 12.90$ have been saved in terms of education, welfare and the criminal justice system (Belfield et al. 2006). However, Barnett (1997) points out that the costs of early childhood education programs in high income countries are often 5-10 times the per capita gross national product of low income countries and may be even more. In addition, the percentage of children aged 0 to 6 years of age is much higher in low income countries and hence Western models of ECE will not be financially feasible. Young (1995) gives some examples of costing data: the ICDS in India is estimated to cost one fifteenth of the minimum wage, the PRONEI program in Peru costs one fourteenth of the minimum wage while a program of parent education in Chile costs one fifth of the minimum wage per child. Behrman and colleagues (2003) estimated the cost-benefit ratios to range from 1.7 to 3.7 for the PIDI program in Bolivia which involves day care, nutrition and educational services to children aged 6-72 months in poor rural areas.

The costs of early childhood stimulation interventions in low income countries have not been systematically examined and the relative costs of different service options are unclear. The coverage of such programs remains low and the costs to be borne by families high and hence services are unlikely to be accessible to 'at risk' families. The challenge is to design services which are of sufficient quality to make an impact and which are targeted to the children who need them most. 


\section{Conclusions and Recommendations}

The evidence cited in this report indicates that early stimulation interventions are effective in improving child and maternal outcomes and these benefits are likely to be sustained over the long term. Interventions should target younger and more disadvantaged children and their families and should involve active involvement of the children's caregivers. Interventions should also promote the well-being of families as a whole, particularly the mothers. Interventions of higher quality, greater intensity and of longer duration are likely to be the most effective.

Further research is required to determine the optimal age for starting early childhood interventions for maximum cost-effectiveness. More research is also required to identify the relative effectiveness of different modes of delivery. For example, group parenting sessions may be a cost-effective method of service delivery but this approach has not been properly evaluated. Programs also need to include measures of cost so that the cost-effectiveness and cost-benefit of early stimulation interventions can be calculated. This is important for changing government policy and for advocating for more funds to be channeled into early childhood intervention services. Identifying mechanisms for wider dissemination of evidence based early childhood stimulation interventions so that they are sustained through routine funding sources while maintaining their effectiveness is also important to ensure broad and continued access to these services. Finally more long-term follow up studies of early childhood stimulation interventions are required with a broad range of measures including child schooling trajectories, academic achievement and economic productivity in adulthood and participants' behavioral outcomes, mental health and life course. More evaluations of the effects of interventions on mothers' wellbeing and life course would also be beneficial in order to delineate the scope of potential outcomes from early childhood interventions. 


\section{References}

Aboud, F. (2007). Evaluation of early childhood parenting program in rural Bangladesh. Journal of Health, Population and Nutrition, 25, 3-13.

Armecin, G., Behrman, J., Duazo, P., Ghuman, S., Gultiano, S., King, E., \& Lee N. (2006). Early childhood development through an integrated program: Evidence from the Philippines. World Bank Policy Research Working Paper, 3922, May 2006.

Baker, H. (2003). A randomized controlled trial of psychosocial intervention with mothers of undernourished children using primary health care services in Jamaica. University College London: Unpublished PhD Thesis.

Baker-Henningham, H., Powell, C., Walker, S., \& Grantham-McGregor S. (2005). The effect of early stimulation on maternal depression: A cluster randomized controlled trial. Archives of Disease in Childhood, 90, 1230-1234.

Barnett, S. (1997). Costs and financing of early child development programs. In M. Young (Ed.), Early child development. Investing in our children's future. (pp. 287-295). Washington D.C.: World Bank.

Barnett, W., \& Belfield, C. (2006). Early childhood development and social mobility. Future of Children, 16, 73-98.

Barros, A., Matijasevich, A., Santos, I., \& Halpern, R. (2009). Child development in a birth cohort: effects of child stimulation is stronger in less educated mothers. International Journal of Epidemiology, 39, 285-294..

Bao, X., Sun, S., \& Wei, S. (1999). Early intervention promotes intellectual development of premature infants: A preliminary report. Chinese Medical Journal (English), 112, 520-523.

Behrman, J., Cheng, Y., \& Todd, P. (2003). Evaluating preschool programs when length of exposure to the program varies: A nonparametric approach. Review of Economics and Statistics, 86, 108-132.

Belfield, C., Nores, M., Barnett, S., \& Schweinhart, L. (2006). The High/Scope Perry Preschool Program: cost-benefit analysis using data from the age-40 follow up. Journal of Human Resources, 41,162-190.

Caribbean Child Support Initiative (2008). Impact study of the Roving Caregivers Program. Research Findings. Retrieved from: http://www.ccsi-info.org/UserFiles/File/RCP \%20Impact\%20Study\%20Findings\%20Summary.pdf on $19^{\text {th }}$ December, 2009. 
Chang, S., Walker, S., Grantham-McGregor, S., \& Powell, C. (2002). Early stunting and later behavior and school achievement. Journal of Child Psychology and Psychiatry, 43, 775783.

Chaturvedi, E. (1987). Impact of six years exposure to ICDS scheme on psychosocial development. Indian Journal of Pediatrics 24, 153-160.

Coleman, J. (1966). Equality of Educational Opportunity. U.S. Department of Health, Education and Welfare, Office of Education, Washington D.C.

Cooper, P., Landman, M., Tomlinson, M., Molteno, C., Swartz, L., \& Murray, L. (2002). Impact of a mother-infant intervention in an indigent peri-urban South African context. British Journal of Psychiatry, 180, 76-81.

Cooper, P., Tomlinson, M., Swartz, L., Landman, M., Molteno, C., Stein, A., McPherson, K., \& Murray, L. (2009). Improving quality of mother-infant relationship and infant attachment in socioeconomically deprived community in South Africa: A randomized controlled trial. British Medical Journal, 338, b974. doi: 10.1136/bmj.b974.

Cunha, F., Heckman, J., Lochner, L., \& Masterov, D. (2005). Interpreting the Evidence on Life Cycle Skill Formation. In: Handbook of the Economics of Education, (eds. E. Hanushek, F. Welch), pp. 697-812. North-Holland, Amsterdam, The Netherlands.

Cunha, F., Heckman, J \& Schennach, S. (2010). Estimating the Technology of Cognitive and Noncognitive Skill Formation. Econometrica, 78 (3), 883- 931

De Souza, N., Sardessai, V., Joshi, K., Joshi, V., \& Hughes, M. (2006). The determinants of compliance with an early intervention program for high-risk babies in India. Child: Care, Health \& Development, 32, 63-72.

Eickmann, S., Lima, A., Guerra, M., Lima, M., Lira, P., Huttly, S., \& Ashworth, A. (2003). Improved cognitive and motor development in a community-based intervention of psychosocial stimulation in northeast Brazil. Developmental Medicine \& Child Neurology, 45, 536-541.

Engle, P., Black, M., Behrman, J., de Mello, M., Gertler, P., Kapiriri, L., Martorell, R., Young, M., \& The International Child Development Steering Group. (2007). Strategies to avoid the loss of developmental potential in more than 200 million children in the developing world. Lancet, 369, 229-242. 
Ertem, I., Atay, G., Bingoler, B., Dogan, D., Bayhan, A., \& Sarica, D. (2006). Promoting child development at sick-child visits: A controlled trial. Journal of the American Academy of Paediatrics, 118, e124-e131.

Gardner, J., Walker, S., Powell, C., \& Grantham-McGregor, SM. (2003). A randomized controlled trial of a home-visiting intervention on cognition and behavior in term low birth weight infants. The Journal of Pediatrics, 143, 634-639.

Grantham-McGregor, S., \& Baker-Henningham, S. (2005). Review of the evidence linking protein and energy to mental development. Public Health Nutrition, 8, 1191-1201.

Grantham-McGregor, S., Cheung, Y., Cueto, S., Glewwe, P., Richter, L., Strupp, B., \& The International Child Development Steering Group. (2007). Developmental potential in the first 5 years for children in developing countries. The Lancet, 369, 60-70.

Grantham-McGregor, S., Lira, P., Ashworth, A., Morris, S., \& Assuncao, A. (1998). The development of LBW term infants and the effects of the environment in northeast Brazil. Journal of Pediatrics, 132, 661-666.

Grantham-McGregor, S., Powell, C., Walker, S., Chang, S., \& Fletcher, P. (1994). The long term follow up of severely malnourished children who participated in an intervention program. Child Development, 65, 428-439.

Grantham-McGregor, S., Powell, C., Walker, S., \& Himes, J. (1991). Nutritional supplementation, psychosocial stimulation and mental development of stunted children: The Jamaican study. Lancet, 338, 1-5.

Grantham-McGregor, S., Schofield, W., \& Harris, L. (1983). Effect of psychosocial stimulation on the mental development of severely malnourished children: an interim report. Pediatrics, 72, 239-243.

Grantham-McGregor, S., Schofield, W., Haggard, D. (1989). Maternal-child interaction in survivors of severe malnutrition who received psychosocial stimulation. European Journal of Clinical Nutrition, 43, 45-52.

Grantham-McGregor, S., Schofield, W., \& Powell, C. (1987). Development of severely malnourished children who received psychosocial stimulation: 6 year follow up. Pediatrics, 79, 247-254. 
Grantham-McGregor, S., Walker, S., Chang, S., \& Powell, C. (1997). Effects of early childhood supplementation with and without supplementation on later development in stunted Jamaican children. American Journal of Clinical Nutrition, 66, 247-253.

Gorman, K., \& Pollitt, E. (1996). Does schooling buffer the effects of early risk. Child Development, 67, 314-326.

Hamadani, J., Hudsa, S., Khatun, F., \& Grantham-McGregor, S. (2006). Psychosocial stimulation improves the development of undernourished children in rural Bangladesh. Journal of Nutrition, 136(10), 2645-2652.

Hamadani, J., Tofail, F., Hilaly, A., Huda, S., Engle, P., \& Grantham-McGregor, S. (2010). The use of indicators of family care and their relation to child development in Bangladesh. Journal of Health, Population and Nutrition 28, 23-33.

Heckman, J. (2006). Skill formation and the economics of investing in disadvantaged children. Science, 312, 1900-1902.

Heckman, J., \& Masterov, D. (2007). The productivity argument for investing in young children. Downloaded from: http://jenni.uchicago.edu/humaninequality/papers/Heckman final all wp 2007-03-22c jsb.pdf on 1st September 2010.

Heckman, J., Stixrud, J. \& Urzua, S. (2006). The Effects of Cognitive and Noncognitive Abilities on Labor Market Outcomes and Social Behavior. Journal of Labor Economics, 24, 411482.

Herrnstein, R., \& Murray, C. (1994). The Bell Curve: Intelligence and Class Structure in American Life. New York: Free Press.

Jin X., Sun, Y., Jiang, F., Ma, J., Morgan, C., \& Shen, X. (2007). Care for Development Intervention in rural China: A prospective follow-up study. Journal of Developmental \& Behavioral Paediatrics, 28, 213-218.

Kagitcibasi, C., Sunar, D., \& Bekman, S. (2001). Long-term effects of early intervention: Turkish low-income mothers and children. Applied Developmental Psychology, 22, 333-361.

Kagitcibasi, C., Sunar, D., Bekman, S., Baydar, N., \& Cemalcilar, Z. (2009). Continuing effects of early enrichment in adult life: The Turkish Early Enrichment Project 22 years later. Journal of Applied Developmental Psychology, doi:10.1016/j.appdev.2009.05.003. 
Klein, P., \& Rye, H. (2004). Interaction-oriented early intervention in Ethiopia: The Mediational Intervention for Sensitizing Caregivers (MISC) Approach. Infants and Young Children, 17, 340-354.

Magwaza, A., \& Edwards, S. (1991). An evaluation of an integrated parent-effectiveness training and children's enrichment program for disadvantaged families. South African journal of Psychology, 21, 21-25.

Maulik, PK., Darmstadt, GL. (2009). Community-based interventions to optimize early childhood development in low resource settings. Journal of Perinatology, 29, 531-542.

McKay, A., \& McKay, H. (1983). Primary school progress after preschool experience: troublesome issues in the conduct of follow-up research and findings from the Cali, Colombia study. In K. King \& R. Meyers (Eds.), Preventing school failure: the relationship between preschool and primary education. (pp. 36-42). Ottawa: International Development Research Center.

McKay, H., Sinisterra, L., McKay, A., Gomez, H., \& Lloreda, P. (1978). Improving cognitive ability in chronically deprived children. Science, 200, 270-278.

Meeks-Gardner, J., Grantham-McGregor, S., Chang, S. (1995). Activity and behavioural development in stunted and non-stunted children and response to nutritional supplementation. Child Development, 66, 1785-1797.

Meeks-Gardner, J., Grantham-McGregor, S., Himes, J., \& Chang, S. (1999). Behavior and development of stunted and non-stunted Jamaican children. Journal of Child Psychology and Psychiatry, 40, 819-827.

Mora, J., Clement, J., Christiansen, N., Ortiz, N., Vuori, L., \& Wagner, M. (1979). Nutritional supplementation, early stimulation and child development. In: Brozek J (Ed.) Behavioral effects of energy and protein deficits. DHEW Pub. no. (NIH) 79-1906 (pp. 255-269).

Mora, J., Guilleramo, M., Sellers, S., \& Ortiz, N. (1981). Nutrition, social environment and cognitive performance of disadvantaged Colombian children at three years. Nutrition in Health and Disease and Internal Development: Symposia from the XII International Congress of Nutrition, 403-420.

Murnane, R., Willett, J. \& Levy, F. (1995). The Growing Importance of Cognitive Skills in Wage Determination. Review of Economics and Statistics, 77, 251-266. 
Myers, R. (1992). The twelve who survive: Strengthening programmes of early child development in the third world. Routledge, London, UK.

Nahar, B., Hamadani, J., Ahmed, T., Tofail, F., Rahman, A., Huda S., \& Grantham-McGregor, S. (2009). Effects of psychosocial stimulation on growth and development of severely malnourished children in a nutrition unit in Bangladesh. European Journal of Clinical Nutrition, 63, 725-31.

Nair, MKC., Philip, E., Jeyaseelan, L., George, B., Matthews, S., \& Padma, K. (2009). Effect of child development centre model early stimulation among at-risk babies - A randomized controlled trial. Indian Pediatrics, 46, S20-S26.

National Research Council and Institute of Medicine. (2000) From neurons to neighborhoods. The science of early child development. National Academy Press, Washington D.C.

Nelson, C., Zeanah, C., Fox, N., Marshall, P., Smyke, A., \& Guthrie, D. (2007). Cognitive Recovery in Socially Deprived Young Children: The Bucharest Early Intervention Project. Science, 318, 1937-1940.

Nores, M., \& Barnett, S. (2010). Benefits of early childhood interventions across the world: (Under) Investing in the very young. Economics of Education Review, 29, 271-282.

Olds, D., \& Kitzman, H. (1993). Review of research on home visiting for pregnant women and parents of young children. The Future of Children, 3, 53-92.

Perez-Escamilla, R., \& Pollitt, E. (1995). Growth improvements in children above 3 years of age: The Cali study. Journal of Nutrition, 125, 885-893.

Pollitt, E., Gorman, K., Engle, P., Martorell, R., \& Rivera, J. (1993). Early supplementary feeding and cognition. Society for Research in Child Development, 58, Monograph No. 7.

Potterton, J., Steward, A., Cooper, P., \& Becker, P. (2010). The effect of a basic home stimulation program on the development of young children infected with HIV. Developmental Medicine and Child Neurology, 52, 547-551.

Powell, C. (2004). An evaluation of the Roving Caregivers Program of the Rural Family Support Organisation, May Pen, Clarendon, Jamaica. UNICEF, Jamaica: Unpublished report.

Powell, C., Baker-Henningham, H., Walker, S., Gernay, J., \& Grantham-McGregor, S. (2004). Feasibility of integrating early stimulation into primary care for undernourished Jamaican children: Cluster randomized controlled trial. British Medical Journal, 329, 89. 
Powell, C., \& Grantham-McGregor, S. (1989). Home visiting of varying frequency and child development. Paediatrics, 84(1), 157-164.

Rahman, A., Iqbal, Z., Roberts, C., \& Husain, N. (2008). Cluster randomized trial to support early development of children in a low-income country. Child: care, health and development, $35(1), 56-62$.

Rahman, A., Malik, A., Sikander, S., Roberts, C., \& Creed, F. (2008). Cognitive behavior therapybased intervention by community health workers for mothers with depression and their infants in rural Pakistan: A cluster-randomized controlled trial. Lancet, 372, 902-909.

Ramey, C., \& Ramey, S. (1998). Early intervention and early experience. American Psychologist $53,109-120$.

Robert, R., Gittelsohn, J., Creed-Kanashiro, H., Penny, M., Caulfield, L., Narro, M., \& Black, R. (2006). Process evaluation determines the pathway of success for a health center-delivered nutrition education intervention for infants in Trujillo, Peru. Journal of Nutrition, 136, 634641.

Santos, D., Assis, A., Bastos, A., Santos, L., Santos, C., Strina, A., Prado, M., Almeida-Filho, N., Rodrigues, L., \& Barreto, M. (2008). Determinants of cognitive function in childhood: A cohort study in a middle income context. BMC Public Health, 8, 202.

Save the Children. (2004). A Positive Impact: A Study from Myanmar of the Effects for Children, their Families and Communities. Westport, CT: Save the Children Federation, Early Childhood Care and Development.

Sharma, S., \& Nagar, S. (2009). Influence of home environment on psychomotor development of infants in Kangra district of Himachal Pradesh. Journal of Social Sciences, 21, 225-229.

Shin, J., Nhan, N., Lee, S., Crittenden, K., Fory, M., \& Hong, H. (2009). The effects of a homebased intervention for young children with intellectual disabilities in Vietnam. Journal of Intellectual Disability Research, 53, 339-352.

Shonkoff, J., Boyce, WT., \& McEwen, B. (2009). Neuroscience, molecular biology, and the childhood roots of health disparities: Building a new framework for health promotion and disease prevention. Journal of the American Medical Association, 301, 2252-2259.

Super, C., Herrera, M., \& Mora, J. (1990). Long term effects of food supplementation and psychosocial intervention on the physical growth of Colombian infants at risk of malnutrition. Child Development, 61, 29-49. 
Super, C., Herrera, M., Mora, J. (1991). Cognitive outcomes of early nutritional intervention in the Bogota study. Abstracts of the meeting of the Society for Research in Child Development, Seattle.

Waber, D., Vuori, L., Ortiz, N., Clement, J., Christiansen, N., Mora, J., Reed, R., \& Guillermo M. (1981). Nutritional supplementation, maternal education and cognitive development of infants at risk for malnutrition. American Journal of Clinical Nutrition, 34, 797-803.

Wachs, T. (2000) Necessary but not sufficient: the role of individual and multiple influences on human development. American Psychological Association Press, Washington D.C.

Wachs, T., Black, M., \& Engle, P. (2009). Maternal depression: A global threat to children's health, development and behavior and to human rights. Child Development Perspectives, 3, $51-59$.

Walker, S., Chang, S., Powell C., \& Grantham-McGregor, S. (2004). Psychosocial intervention improves the development of term low birth weight infants. Journal of Nutrition, 134, 1417-1423.

Walker, S., Chang, S., Powell, C., \& Grantham-McGregor, S. (2005). Effects of early childhood psychosocial stimulation and nutritional supplementation on cognition and education in growth-stunted Jamaican children: Prospective cohort study. Lancet, 366, 1804-1807.

Walker, S., Chang, S., Powell, C., Simonoff, E., \& Grantham-McGregor, S. (2006). Effects of psychosocial stimulation and dietary supplementation in early childhood on psychosocial functioning in late adolescence: Follow-up of randomized controlled trial. British Medical Journal, 333, 472. doi:10.1136/bmj.38897.555208.2F.

Walker, S., Chang, S., Younger, N., \& Grantham-McGregor, S. (2010). The effect of psychosocial stimulation on cognition and behavior at 6 years in a cohort of term, low-birthweight Jamaican children. Developmental Medicine and Child Neurology, 52, e148-154.

Walker, S., Grantham-McGregor, S., Himes, J., Powell, C., \& Chang, S. (1996). Early childhood supplementation does not benefit the long term growth of stunted children in Jamaica. Journal of Nutrition, 126, 3017-3024.

Walker, S., Grantham-McGregor, S., Powell, C., \& Chang, S. (2000). Effects of growth restriction in early childhood on growth, IQ and cognition at age 11 to 12 years and the benefits of nutritional supplementation and psychosocial stimulation. Journal of Pediatrics, 137, 3641. 
Walker, S., Powell, C., Grantham-McGregor, S., Himes, J., \& Chang, S. (1991). Nutritional supplementation, psychosocial stimulation and growth of stunted children: The Jamaican study. American Journal of Clinical Nutrition, 54, 642-648.

Walker, S., Wachs, T., Gardner, J., Lozoff, B., Wasserman, G., Pollitt, E., Carter, J., \& the International Child Development Steering Group. (2007). Child development: risk factors for adverse outcomes in developing countries. Lancet, 369, 145-157.

Wantanabe K., Flores R., Fujiwara J., \& Tran L. (2005). Early childhood development interventions and cognitive development of young children in rural Vietnam. The Journal of Nutrition, 135, 1918-1925.

Wendland-Carro, J., Piccinini C., Millar, W. (1999). The role of an early intervention on enhancing the quality of mother-infant interaction. Child Development; 70, 713-721.

WHO. (1999). The Critical Link. Interventions for physical growth and psychological development. A review. Geneva: Department of Child and Adolescent Health, World Health Organisation.

Yoshikawa, H. (1995). Long term effects of early childhood programs on social outcomes and delinquency. Future of Children, 5, 51-75.

Young, M. (1995). Investing in young children. Washington, D.C.: World Bank. 